\title{
Interstate Migration of the US Poverty Population: Immigration "Pushes" and Welfare Magnet "Pulls"
}

\author{
William H. Frey \\ The University of Michigan \\ Kao-Lee Liaw \\ McMaster University \\ Yu Xie \\ The University of Michigan \\ Marcia J. Carlson \\ The University of Michigan
}

This study evaluates the social and demographic structure of poverty migration during the 1985-90 period based on an analysis of recent census data. Particular attention is given to the roles of two policy-relevant factors that are proposed to be linked to poverty migration. The first of these is the role of immigration from abroad and its effect on the net out-migration of longer-term residents with below-poverty incomes, from States receiving the highest volume of immigrants. Such a response, it is argued, could result from job competition or other economic and social costs associated with immigration. The second involves the poverty population "magnet" effect associated with State welfare benefits (AFDC and Food Stamp payments) which has come under renewed scrutiny in light of the impending reform of the

This research is supported by the University of Wisconsin Institute for Research on Poverty Small Grants Program and by NICHD grant No. R01 HD29725. The migration data for this paper were prepared at the Population Studies Center, University of Michigan from 1990 US Census files. The authors acknowledge Cathy Sun for computer programming assistance, and Ron Lue-Sang for preparing maps and graphics.

Please address correspondence to Dr. Frey, Population Studies Center, University of Michigan, 1225 South University Avenue, Ann Arbor, MI 48104-2590.

Population and Environment: A Journal of Interdisciplinary Studies

Volume 17, Number 6, July 1996

(C) 1996 Human Sciences Press, Inc. 


\section{POPULATION AND ENVIRONMENT}

federal welfare program. The impact of both of these factors on interstate poverty migration is evaluated in a broader context that takes cognizance of other sociodemographic subgroups, and State-level attributes that are known to be relevant in explaining internal migration. This research employs an exceptionally rich data base of aggregate migration flows, specially tabulated from the full migration sample of the 1990 US census (based on the "residence 5 years ago" question). It also employs an analysis technique, the nested logit model, which identifies separately the "push" and "pull" effects of immigration, welfare benefits, and other State attributes on the migration process. Our findings are fairly clear. The high volume of immigration to selected US States does affect a selective out-migration of the poverty population, which is stronger for whites, Blacks and other non-Asian minorities as well as the least-educated. These results are consistent with arguments that internal migrants are responding to labor market competition from similarly educated immigrants. Moreover, we found that the impact of immigration occurs primarily as a "push" rather than a reduced "pull." In contrast, State welfare benefits exert only minimal effects on the interstate migration of the poverty population-either as "pulls" or "pushes," although some demographic segments of that population are more prone to respond than others. In addition to these findings, our results reveal the strong impact that a State's racial and ethnic composition exerts in both retaining and attracting migrants of like race and ethnic groups. This suggests the potential for a greater cross-state division in the US poverty population, by race and ethnic status.

Data Used: 1990 US census tabulations of full migration ("residence 5 years ago") sample. Note: Detailed 1990 census statistics on migration of the poverty and nonpoverty populations for individual states can be found in: William H. Frey "Immigration and Internal Migration for US States: 1990 Census Findings by Poverty Status and Race," Population Studies Center Research Report No. 94-320.

\section{INTRODUCTION}

This research evaluates the social and demographic structure of poverty migration during the $1985-90$ period and its impact on States' poverty populations. Particular attention is given to the roles of two policy-relevant factors that have been linked to inter-State migration in recent debates:

1. Immigration from abroad. The first of these is the role of immigration from abroad and its effect on the net out-migration of native-born Americans from States receiving the highest volume of immigrants (e.g., especially California). Both descriptive migration statistics and analyses based on the 1990 census (Frey, 1994b; 1995a; 1995b; The Washington Post, 1993) and of the 1980 census (Walker, Ellis \& Barff, 1992; Filer, 1992; White \& Hunter, 1993) suggest that it is the least educated, lowincome and poverty residents who are leading the way out, apparently, in response to competition from low-skilled immigrants. While employmentbased admissions have been given higher priority in the Immigration Act of 
W. FREY, K.-L. LIAW, Y. XIE, AND M. CARLSON

1990, these admissions still constitute only a small part of the overall immigration flow and there is the possibility of further adjustment (Fix \& Passel, 1994; Martin, 1993). Moreover, governors of the most heavily impacted States are beginning to call for more drastic State and federal-level legislation to reduce the incentives for continued high immigration levels, (The New York Times, 1993; 1994).

2. Welfare benefits. The second policy-relevant factor to be emphasized involves the poverty population "magnet" effect that has often been linked to a State's welfare payments, particularly those associated with AFDC (Aid to Families with Dependent Children). This linkage has come under renewed scrutiny in States with generous welfare benefits and because of the impending reform of the federal welfare program. Considerable research has examined the linkage between welfare benefits and migration (Cebula, 1979; Cebula \& Belton, 1994; Southwick, 1981; Gramlich \& Laren, 1984; Blank, 1988; Clark, 1991; Peterson \& Rom, 1990; Voss, Corbett \& Randell, 1992; Cushing, 1993; Hanson \& Hartman, 1994; Walker, 1994; Schram \& Krueger, 1994; see also review in Moffitt, 1992). The most recent of these, employing sample survey data or with limited geographic coverage, suggest that this linkage is relatively modest. However, the kinds of data used in these studies were too limited to make inferences about the aggregate redistribution impacts for States associated with migration flows of detailed sociodemographic subpopulations that are known to respond differently to State area-level "pushes" and "pulls" in addition to the effects of welfare benefits. These limitations were, in part, a consequence of the unavailability of the full census sample migration matrix, which is required for such an analysis. The present study employs such a data base specially tabulated from the 1990 US census.

This study is divided into two parts. The first section reviews detailed 1990 census findings on the patterns of State gains and losses in poverty populations. The questions addressed here are: Which States gain largest net numbers of poverty migrants via internal migration? Which States lose largest net numbers of poverty migrants? Are these State patterns of net migration associated with the policy factors-recent immigration from abroad, and high welfare benefits?

The second section of the analysis goes beyond a description of State net migration patterns toward an examination of the migration process. Focussing on the most mobile age groups, it evaluates two separate parts of the migration process: factors which affect the magnitude of State out-migration flows, and factors which affect the drawing power of destination States. For each part of the migration process, we evaluate the relative importance of State immigration levels, and State welfare benefits, vis-à-vis 
POPULATION AND ENVIRONMENT

other factors known to influence migration, in order to determine if these factors exert separate "pushes" or "pulls" on inter-State migration streams. Moreover our analysis technique, the nested logit model, allows us to examine the extent to which these factors are more likely to impact upon key population subgroups - by race, gender, education, US nativity - in affecting inter-State migration of the US poverty population. Are welfare benefits most likely to exert a "pull" on migration streams of poor women? Are high school dropouts most likely to be "pushed" away from high immigration States? These questions are among those addressed in our examination of the migration process.

Overall, our findings show that immigration to a few port-of-entry States exerts a far larger impact on the internal migration of the nation's poverty population-acting as a "push," than do State welfare benefits, acting as "pulls." This finding, from our examination of the migration process, is consistent with observed patterns of State net losses and gains. The large net out-migration of poverty migrants from High Immigration States reflects some response to immigration, independent of other influences on the migration process. This response is especially evident among whites, Blacks, and the least educated. In contrast, our results show that State welfare benefits (AFDC and Food Stamps, combined) exert only minimal effects on the inter-State migration of the US poverty population-either as "pulls" or "pushes," although some demographic segments of that population are more prone to respond than others. These patterns are discussed more fully in the second part of the analysis.

\section{MIGRATION DATA}

The migration data for this study are drawn exclusively from tabulations of the fixed interval 5-year migration question of the 1990 US decennial census. This is the only nation-wide data set available that is appropriate for examining aggregate migration stream processes associated with detailed regions and population subgroups. The main State origin-to-destination matrix for 1985-90 migration stream and non-migrant populations is disaggregated by age (5-year age groups), gender (males, females), education attainment (less than high school, high school graduate, some college, college graduate), race-ethnic status (non-Hispanic Whites, Blacks, Asians, Hispanics, American Indians),' nativity (US-born, foreign-born), and pov-

\footnotetext{
${ }^{1}$ Because the census tabulations that were made available for this study did not provide a cross-classification of the separate variables, race and Hispanic origin, we developed a pro-
} 
W. FREY, K.-L. LIAW, Y. XIE, AND M. CARLSON

erty status (below poverty income, above poverty income) where most of the present study will focus exclusively on the poverty population. Despite the obvious strengths of using census data for this aggregate migration and redistribution analysis, a well-known weakness is the unavailability of population characteristics at the beginning of the 1985-90 period, since only characteristics that could be identified at census time are available. This limitation is particularly noteworthy for the poverty population, defined in the 1990 census on the basis of 1989 income. Hence, the poverty population as defined here only approximates the poverty population that may have existed at any point over the $1985-90$ period.

\section{STATE PATTERNS OF POVERTY MIGRATION}

Before discussing the gain and loss patterns of recent poverty migration, we focus first on those States which are particularly relevant to our policy factors: High Immigration States and High Welfare Benefit States (see Table 1). The High Immigration States are identified elsewhere (Frey, 1994a) and include the six States with greatest numeric immigration gains. They include: California, New York, Texas, New Jersey, Illinois and Massachusetts. (Note: While Florida also attracts a large number of immigrants, our earlier typology of States by migration status (Frey, 1994a) classes it as a High Internal Migration State because internal migration rather than immigration dominates its population gain.) The High Welfare Benefit States represent those with greatest combined AFDC and Food Stamp benefits, when adjusted for State cost-of-living differences (see Appendix B for definition and State values). They include two High Immigration States, California and New York, as well as Vermont, Wisconsin, Washington, Minnesota, Oregon, Utah, Kansas and Rhode Island. (Alaska and Hawaii are excluded because comparable welfare benefit information was unavailable.)

The data in Table 1 show that the observed net internal migration rates

cedure to collapse these two variables into a single one. This was done by, first, classifying all persons of the races, Black, Asian (including Pacific Islanders), and American Indian (including Eskimos and Aleuts) according to their actual reported races. Persons reporting a Hispanic origin were classed as Hispanics. The non-Hispanic white population was, therefore, estimated by subtracting persons who identified themselves as Hispanics on the Hispanic origin item, from the total of persons identifying themselves as either white or as "other" on the race item. The resulting, mutually exclusive, categories are: Blacks, Asians, American Indians, Hispanics, and non-Hispanic whites This procedure tends to understate non-Hispanic whites in States where more than a minimal number of Hispanics are Black or Asian. For convenience, this paper will refer to non-Hispanic whites as simply "whites." 


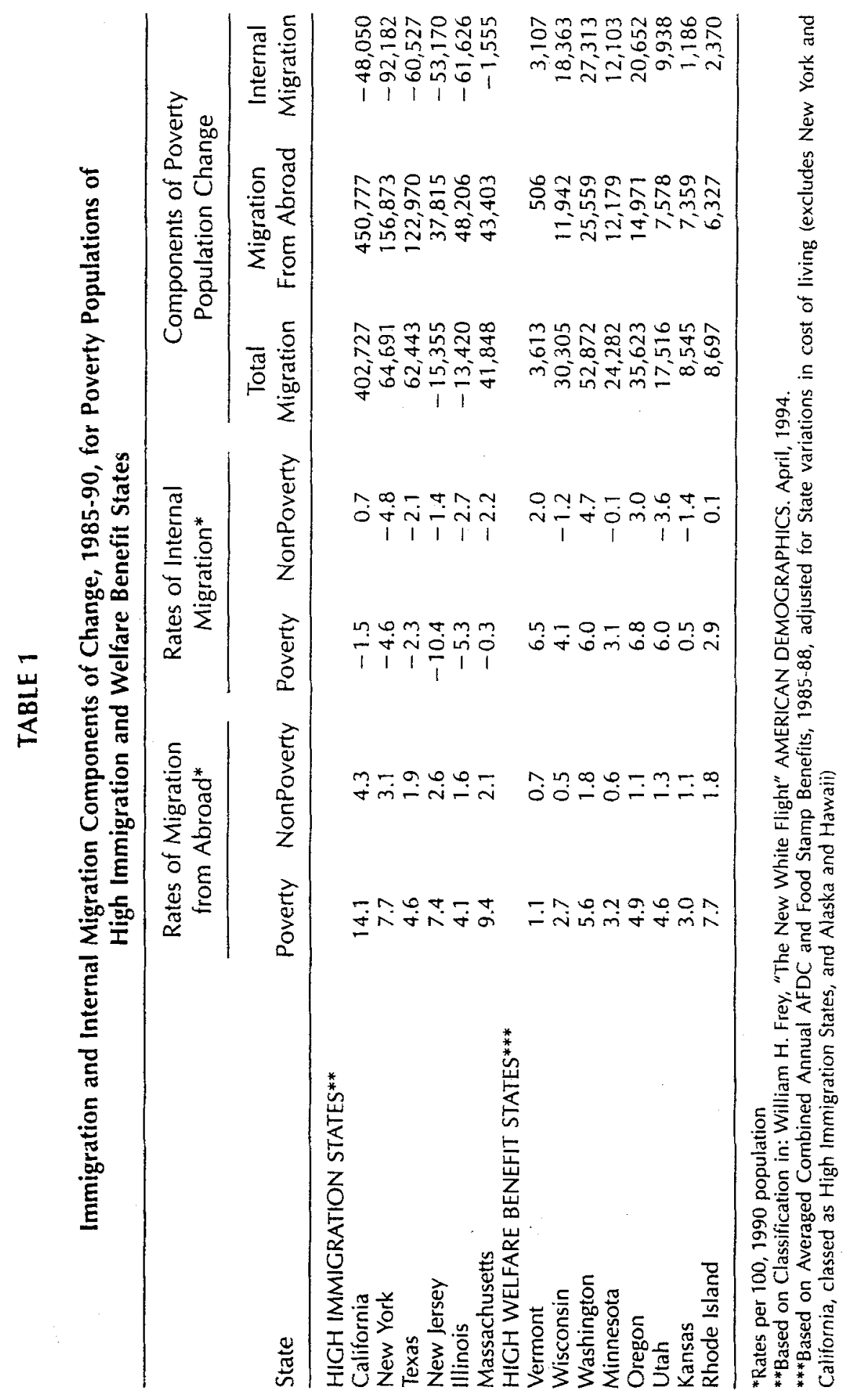


W. FREY, K.-L. LIAW, Y. XIE, AND M. CARLSON

for the poverty and nonpoverty populations in most of these States are consistent with prior expectations. That is, for four of the High Immigration States, rates of net internal out-migration for the poverty population are higher than those for the non-poverty population. (For New York, both rates are relatively high though slightly higher for the nonpoverty population.) By the same token, each of the High Welfare Benefit States (which are not also High Immigration States) show higher rates of net internal inmigration for the poverty population than for the nonpoverty population.

In both instances, these patterns counter the conventional wisdom. The conventional pattern, well-established in the migration literature (Long, 1988), shows migration to be most selective on positive demographic characteristics-high incomes, high educations, higher-skilled occupations. This is because it is these segments of the labor force which are most responsive to national income and employment opportunities because of their valued human capital attributes, and the more specialized nature of their occupations. The redistribution process, then, might be characterized as a "circulation of elites" (Frey, 1979). The process typically sees employment-gaining States as attracting higher rates of nonpoverty, college graduate migrants, than rates of poverty or lower-skilled migrants. By the same token, migration-losing States show greater rates of outflow among their nonpoverty, and college graduate migrants. The patterns shown here, for High Immigration States and for High Welfare Benefit States, differ from those conventional patterns shown for other States (Frey, 1994b), and suggests that there may be unique immigration and welfare benefit effects on the migration of the poverty population.

Another noteworthy aspect of the redistribution pattern for High Immigration States, is the net impact of immigration from abroad vis-à-vis internal migration on changes in the overall poverty population for the State. As Table 1 shows, each of the High Immigration States shows a negative net internal migration of the poverty population over the 1985-90 period. However, this net loss among internal poverty migrants is more than compensated by gains in the poverty population via immigration from abroad. (See right-hand panel in Table 1.) In contrast, the migration dynamics within the High Welfare Benefit States is influenced much more strongly by the internal migration process, so that the poverty gains attributed to internal migration over the $1985-90$ period either dominate or largely contribute to the overall poverty migration gains for the State. The relative impact of immigration and internal migration for poverty population gains will be discussed at the conclusion of this paper, especially as it relates to High Immigration States. However, the main focus of this investigation involves evaluating patterns and determinants of internal migration of the poverty population across States. 


\section{Patterns of Migration Gains and Losses}

While the above discussion focussed on poverty migration patterns specifically for the High Immigration States and High Welfare Benefit States, we will now turn to an examination of overall State patterns of gains and losses with respect to internal migration of the poverty population. Are the greatest poverty migrant gaining States also the High Welfare Benefit States? Are the greatest poverty migration losing States also the High Immigration States? How do these patterns differ across key demographic subgroups? These questions are addressed here.

The first column in Table 2 lists the greatest net migration gaining and losing States, among the poverty population, over the 1985-90 period. The most noticeable aspect of these patterns is that the largest net out-migrations of poverty populations are associated with five High Immigration States, which dominate all other States in the magnitudes of their poverty out-migrations-ranging from $-92,000$ to $-48,000$ for New York, Illinois, Texas, New Jersey and California.

In contrast, the greatest poverty net in-migration States are not dominated by those with high welfare benefits. Rather, Florida leads the list by a fairly wide margin, which is also the case for the nonpoverty population which is not shown here. Three High Welfare Benefit States, Washington, Oregon, and Wisconsin, are among the ten top poverty gainers-all higher in rank than they appear on the similar list for the nonpoverty population. Nonetheless, States that gain in poverty population are a mix among those with a relatively high growth in service industry employment opportunities (Florida, North Carolina, Georgia, Tennessee), retiree magnets (Florida, Arizona), as well as some of the High Welfare Benefit States. An additional factor, suggested by this list, is a spillover movement to nearby States of poverty migrants leaving California (for Washington, Oregon and Arizona) or Illinois (for Wisconsin).

A comparison of the poverty gainers and losers with a corresponding list for the nonpoverty population (Appendix A) indicates one important difference: both gainers and losers for the nonpoverty population are more apt to have growing and declining economies, respectively. For example, Virginia and Maryland, located in the prosperous South Atlantic region, appear among the top ten nonpoverty magnets, and the economically dynamic State of Georgia ranks second next to Florida in attracting nonpoverty populations from other States. Moreover, additional economically declining States appear on the list of migration losers for the nonpoverty population. These include Michigan and Ohio from the deindustrializing rust belt, Oklahoma, from the oil patch region, and lowa which witnessed 


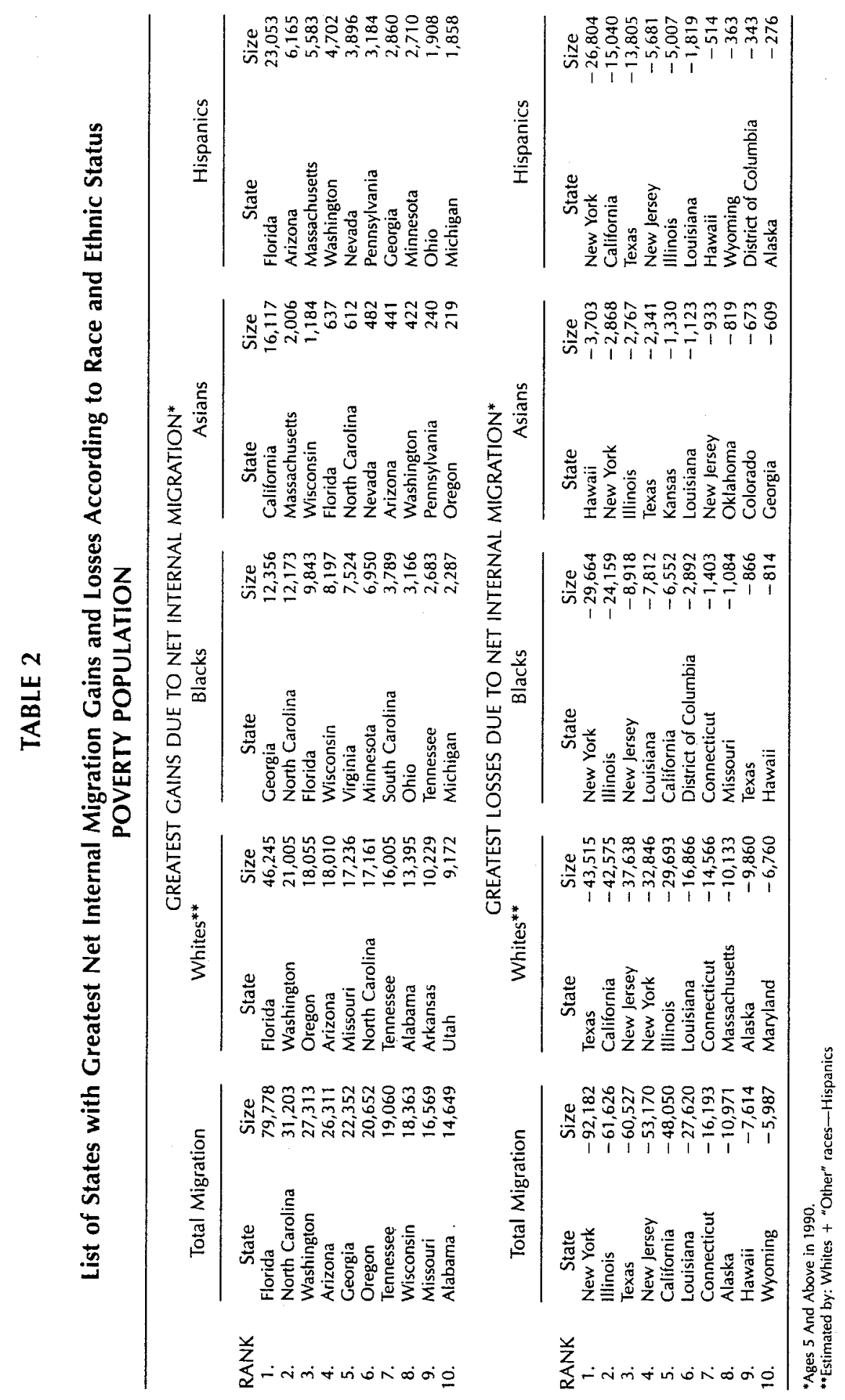


downturns in farming during this period. Although five High Immigration States also appear on this list-including the three top losers, New York, Texas and Illinois - the out-migration of nonpoverty population is not coming primarily from High Immigration States.

This relates to an important contrast between inter-State migration patterns for the poverty population and the nonpoverty population (see Map 1). The net out-migration from the poverty population is heavily focused on a few origin States, dominated primarily by the High Immigration States. The number of net in-migration States is relatively large and much more diffuse. This represents a "push-oriented" migration process. In contrast, the net migration of nonpoverty population tends to be more "pull-oriented" in that the number of net in-migration States is much smaller, and represent economically prosperous States located mainly on the coastal parts of the US. It is interesting to note that California represents an outmigration State for poverty migrants, and an in-migration State for nonpoverty migrants. This may be attributable to the fact that it is largely the poverty and less-skilled segment of the California population that is competing with immigrants in the labor market. The nonpoverty population, as with the college graduate population (see Frey, 1995b) may be operating in a somewhat different labor market where the effect of recent immigration may actually complement rather than compete with their employment opportunities (White \& Hunter, 1993).

The data in Table 2 also break down States gaining and losing poverty migrants by race and ethnicity. Particularly for whites and Blacks, States with greatest poverty net out-migration are most represented by High Immigration States. Among whites, the same five High Immigration States dominate poverty out-migration, as was the case with the total population. These States, along with Massachusetts, dominate most of losing States for poverty whites, much more so than they do for the nonpoverty white population (see Appendix A). Among Blacks, Illinois rivals New York as the largest net exporter of poverty out-migrants, unlike the case with the nonpoverty Black population. Moreover, New Jersey, California and Texas, each on the list of greatest Black poverty net exporting States are not on the comparable list for nonpoverty Blacks. The out-migration of nonpoverty Blacks appears to be more accentuated in economically struggling States (Louisiana, Mississippi, Pennsyivania, Michigan).

While there is some similarity in the largest net out-migration States for white and Black poverty migrants, this is less the case for their net inmigration destination States (see Map 2). This reflects, in part, the different geographic concentrations of the two races as well as their historic roots (Long, 1988; McHugh, 1987; Johnson \& Roseman, 1990). Poverty Blacks, 
MAP 1.

\section{Net Internal Migration}
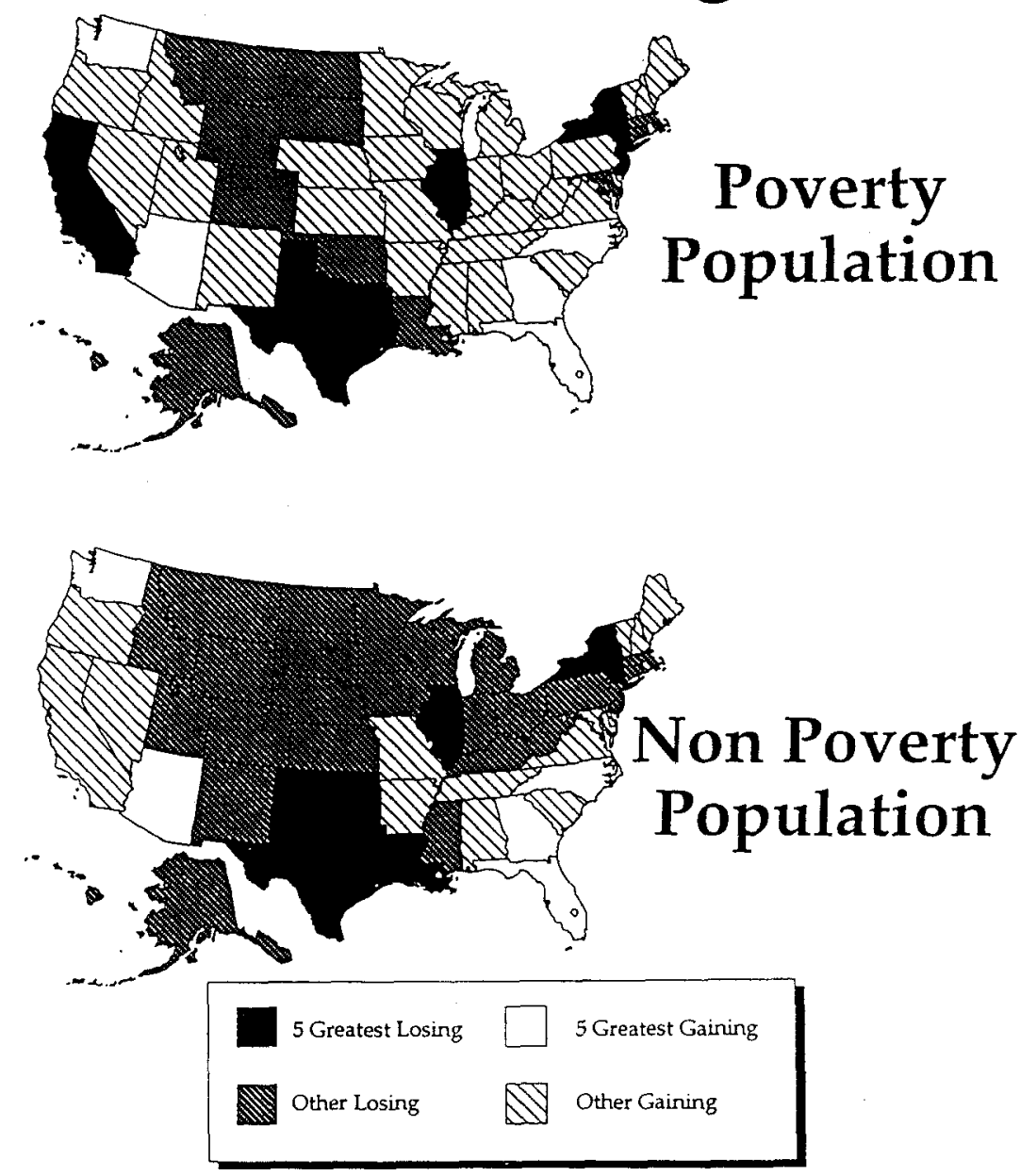

for example, are more apt to relocate in the South Atlantic, especially to Georgia and North Carolina. For whites, Florida remains the number one gainer followed by States that lie nearby California. While High Welfare Benefit States do not dominate each list, they are more prominent as gainers for poverty whites and Blacks than they are for these races' non- 
MAP 2.

\title{
Net Internal Migration
}

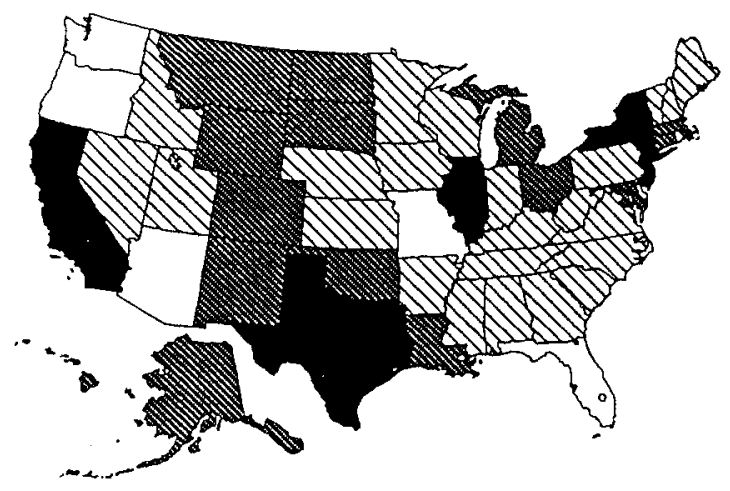

\author{
Poverty \\ Whites
}

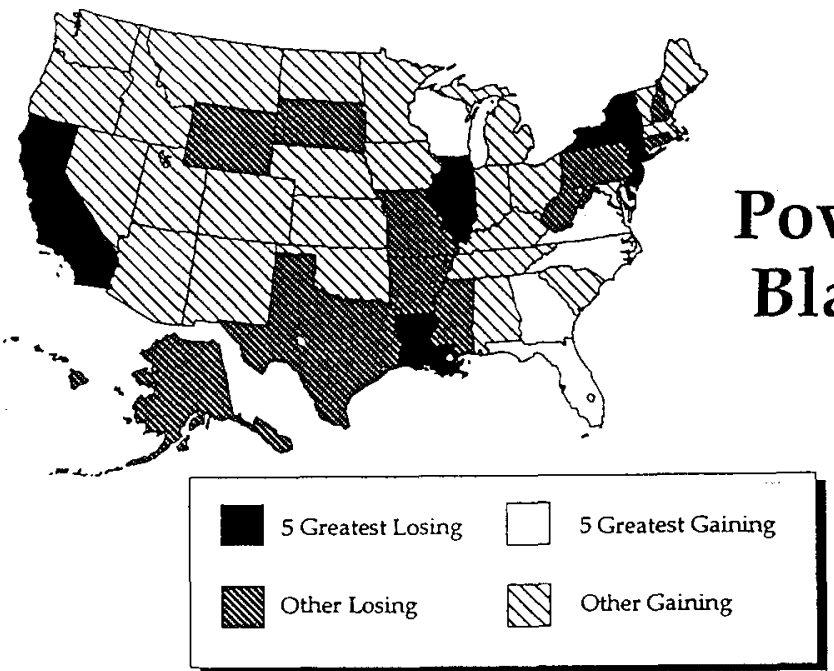

poverty counterparts (see Appendix $\dot{A}$ ). This is the case for Washington and Oregon, among whites. Among Blacks, Wisconsin and Minnesota are among the top six gaining States for the poverty population, and do not appear among the top ten for the non-poverty population.

The greatest gaining and losing States for poverty Asians and His- 
MAP 3.

\title{
Net Internal Migration
}

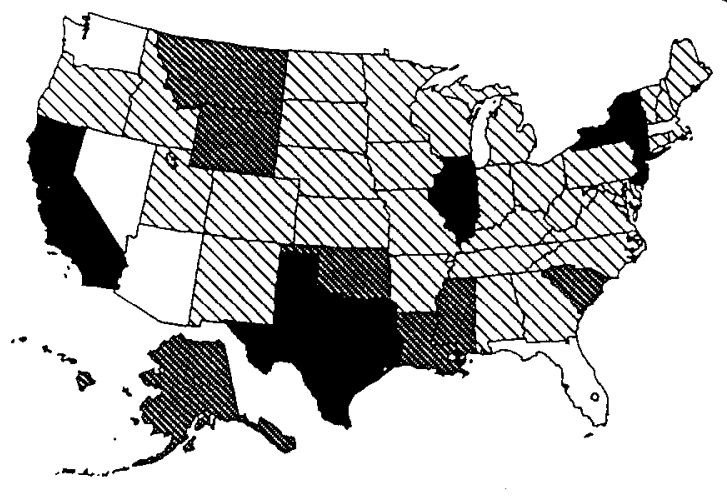

\author{
Poverty
}

Hispanics

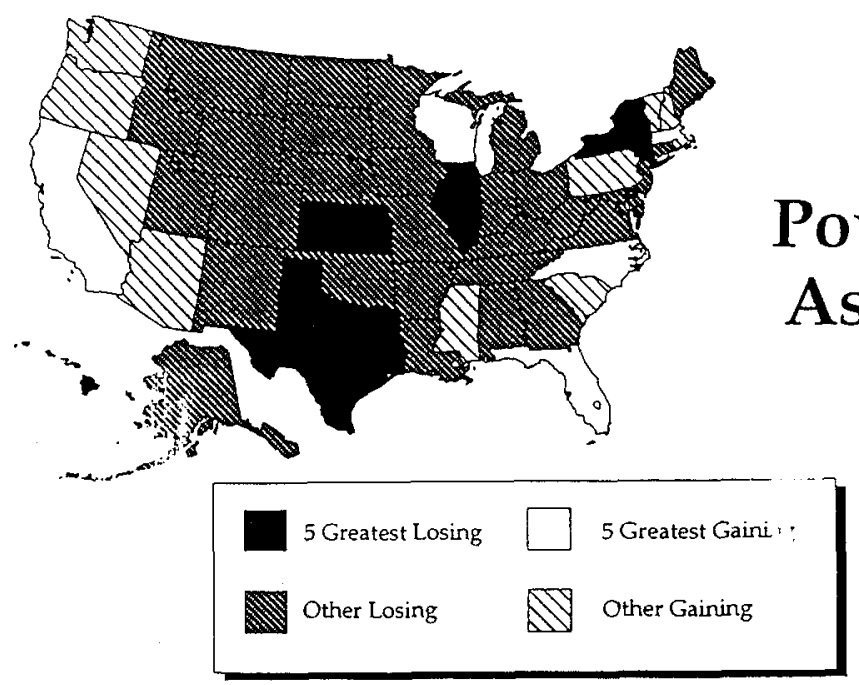

panics are also shown in Table 2. However, these geographic patterns are not distinctly different from those of these groups' nonpoverty counterparts (see Appendix. A). Asian poverty net out-migration is highest in Hawaii, New York, Illinois and Texas--the same four States which dominate Asian nonpoverty net out-migration (although Hawaii ranks fourth rather than 
first). For Hispanics, New York, California and Texas constitute the largest poverty net out-migration States. These same three States dominate the list of nonpoverty Hispanic out-migrants, although movement away from California is less prominent among this group. Finally, nonpoverty Asians and Hispanics are overwhelmingly attracted to single-destination States-California for the former, and Florida for the latter. These attractions appear to have less to do with welfare benefits than traditional ethnic ties or established chain migration patterns (Barringer, Gardner \& Levin, 1993; McHugh, 1989; Frey, 1995a). Hence, both Asian and Hispanic poverty patterns, across States, do not appear to reflect the influences of either welfare benefits or immigration "pushes," as much as whites and Blacks. Although poor Asians and Hispanics show greatest out-migration from several of the High Immigration States, these patterns do not differ significantly from their nonpoverty population counterparts. One exception is the somewhat higher out-migration for poor Hispanics from California, perhaps responding to increased employment competition with immigrants.

\section{State Attributes and Net Poverty Migration}

Another way to evaluate the relationships between our two policy variables (State immigration levels and State welfare benefits) and internal poverty migration for States is a multivariate analysis approach. We present such analyses in Tables 3 and 4 where a State's poverty net migration level for 1985-90 is regressed on a series of State attributes, including our two policy variables as measured by: immigration (level) from abroad, 1985-90; and the combined AFDC and Food Stamp benefits level (average of annual 1985 and 1988 values, adjusted for State cost of living variations). The other State attributes included in the analyses represent economic factors which are known to affect migration (percent of change in manufacturing employment, 1985-89; percent of change in service employment, 1985-89; average per capita income, 1985-1989, with State cost of living adjustments; unemployment rate, 1985), the violent crime rate, averaged over 1985-89, a geographic regional classification of States (dummy variables for the Northeast region, the Midwest region, the South Atlantic division, the Mountain division and the Pacific division, where parts of the South, which are not included in the South Atlantic division, represent the omitted category) and the log of the State's 1985 population size (controlling for scale). Each of the equations in Tables 3 and 4 pertain to net migration for a specific demographic subgroup. This permits us to evaluate the significance of immigration and welfare benefits vis-à-vis other State attributes in affecting State internal migration for different demographic categories of the poverty population. 


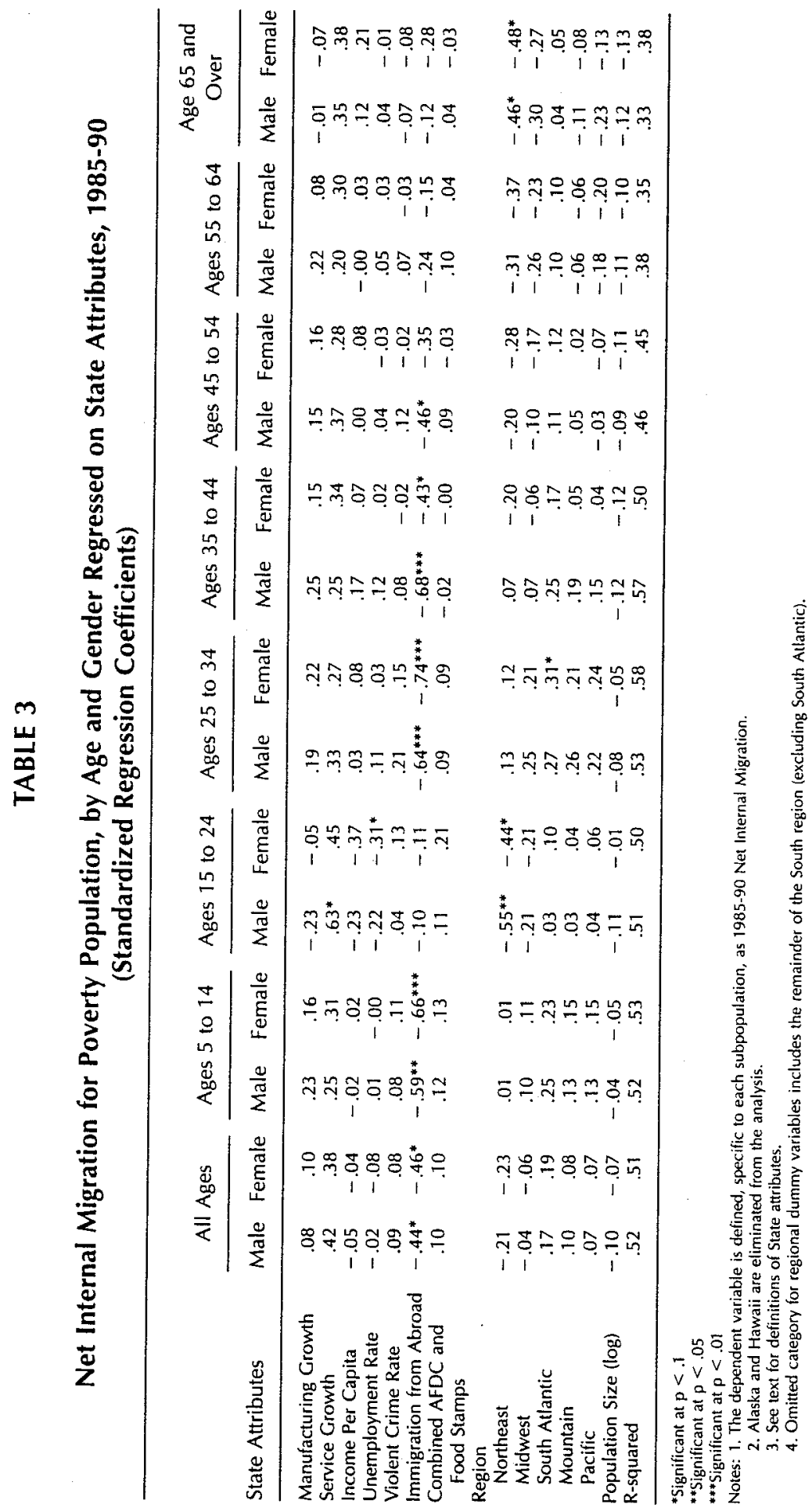




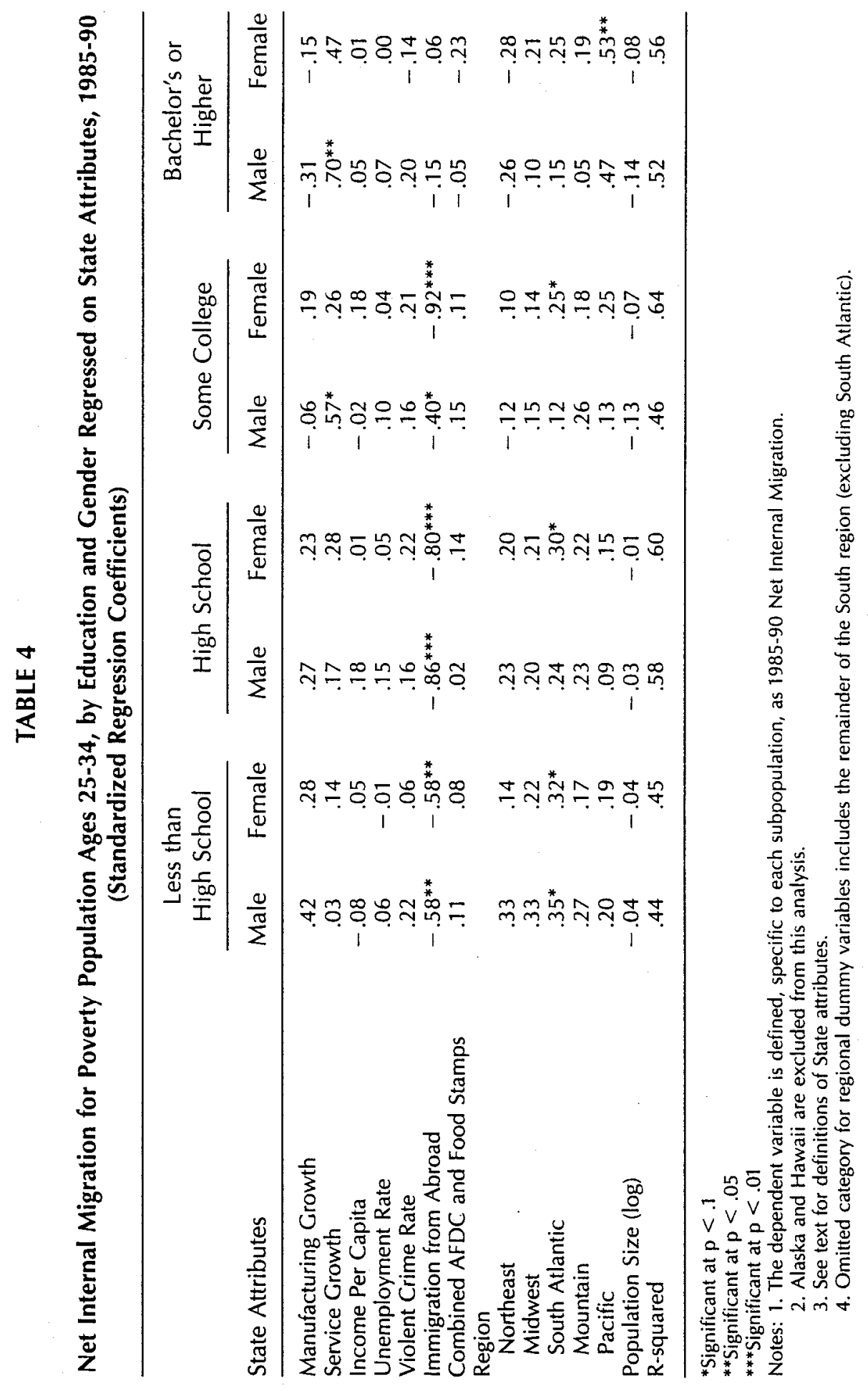


W. FREY, K.-L. LIAW, Y. XIE, AND M. CARLSON

The first two columns of Table 3 present the results of this analysis for the total poverty populations of males and females, respectively. The gender-specific analyses are undertaken because we anticipate that migration of poor women (and children) will be most responsive to a State's welfare benefits. However, the results show clearly that of the two policy variables, immigration alone shows a significant and strong negative impact on State internal migration levels. For neither males nor females does the welfare benefit factor show up to be strong. The only other State attribute which shows a relatively large effect on State poverty migration, for both males and females (as measured by the magnitude of the standardized regression coefficient), is the service employment growth variable.

The analyses of the remaining age groups on Table 3 show that these same variables are dominant for the primary labor force age categories, 25-34, 35-44, and 45-54, as well as for ages 5-14 which can represent the children of people in the former ages. The net migration of both males and females in these age categories shows a relocation away from High Immigration States, toward States with growth in their service industries, especially those located in the South Atlantic region. The impact of State welfare benefits appears to be almost negligible for the poor people in these age categories.

The three age categories where immigration does not show a strong impact on poverty migration are those which do not include the primary labor force years: ages 15-24, ages 55-64, and ages 65 and above. The migration of the former age group, over the $1985-90$ period, really pertains to movement away from the parental home, to college or the military, and to a first but not a career job. The latter two age groups are comprised, to an increasing extent, of retirees or near-retirees. Factors which do show up to be significant for the migration of the 15-24 age group are a State's service employment growth level, and its unemployment rate. These individuals also are exceptionally likely to leave the Northeast region. Further, migration for women in this group show the strongest positive relationship to State welfare benefits, of any of the age groups examined. Yet, the relationship is still relatively small and statistically insignificant.

The net migration of poor people in the elderly age categories appears to be associated with States that have high service employment growthreflecting, perhaps, the need for service industry workers to cater to the elderly in these States. Not unexpectedly, both the pre-elderly and elderly populations show a strong tendency toward net out-migration from the "snow belt" States in the Northeast and Midwest census regions. These findings for the elderly, pre-elderly and post-teenage populations which are not responsive to immigration from abroad, stand in contrast to the strong 
negative impact immigration appears to exert on the population in the primary labor force ages. It adds further evidence to the argument that poor people are moving in response to competition from immigrants for employment in these areas.

Further evidence, supporting this view, appears on Table 4 which focuses only on the poverty population in the age 25-34 age group, specific to different levels of education. These analyses make clear that immigration from abroad holds its greatest negative impact on the net migration of men and women with less than high school, high school and some college. In contrast, the migration of poverty men and women with bachelor's degrees is not responsive to immigration. It is the former group which is perhaps most vulnerable in competing with immigrants for new employment. Two other contrasts can be made between the less-educated and college graduate poverty populations shown here. It is that the former groups appear to be more positively responsive to manufacturing employment growth opportunities, whereas the latter are strongly drawn to States with high levels of service employment growth. Secondly, the former groups are more strongly drawn to States in the South Atlantic region, whereas the latter are more greatly attracted to Pacific-region States. These data, coupled with the age-specific analyses reviewed above, point up the importance of a State's immigration levels toward inducing out-migration of its poverty population, particularly among the less-skilled within primary labor force ages. In contrast, none of the analyses shown above suggests that State welfare benefits are important in affecting State net migration levels for the poor.

\section{STATE ATTRIBUTES AND THE MIGRATION PROCESS}

The previous section has presented an overview of State net migration gains and losses along with a multivariate analysis which suggests that immigration but not welfare benefits are important in effecting those gain and loss patterns. The analysis of net migration for individual States represents an assessment of the outcome of more complicated migration processesinvolving migration streams to and from each of the States. While useful in evaluating the outcomes of the migration process, the net migration analysis does not provide information about the relative importance of "pushes" and "pulls" of specific migration streams, and the importance of our policy factors-immigration and welfare benefits-in affecting this more complex process. It is in this section that we address the process of migration, and the roles of these two policy factors vis-à-vis other migra- 
tion determinants in affecting the magnitude of out-migration from a State-as distinct from what the "drawing power" they exert in attracting in-migrants from other States.

The ability to distinguish an attribute's "push" from its "pull" effects on migration streams has important policy implications. For example, if it were found that the magnitude of State welfare benefits had more "pull" than "push" effects, then lowering those benefits would not necessarily induce an out-migration of the poverty population, even though raising them would attract poor migrants from other States. Or if immigration exerted stronger "push" than "pull" effects on a State's internal migration, then legislation which would restrict immigration to that State would serve to directly reduce internal out-migration to other States.

To assess both the "push" and "pull" effects of State attributes on the inter-State migration process of the poverty population, we employ the nested logit model which has been popularized by Liaw (Liaw \& Bartels, 1982; Liaw \& Ledent, 1987, 1988; Liaw, 1990; Liaw \& Ottomo, 1991). Using this approach, the "push" effects are assessed via a Departure Model, and the "pull" effects (allocation of migrants to destinations) are assessed via a Destination Selection Model (see Figure 1). In these analyses, we evaluate the State attributes, shown in Figure 2, as origins in the Departure Model and as destinations in the Destination Selection Model. Specific attention is given to immigration from abroad (defined here as the immigration rate), and State welfare benefits (as measured above). Each model focuses on two age groups: age 25-29, and 30-34 in order to exam-

FIGURE 1. Nested logit model of interstate migration.

- DESTINATION MODEL (FOR MIGRANTS)

-49 ORIGIN STATES X 48 DESTINATION STATES

- STATE ATTRIBUTES

-POPULATION SUBGROUPS

- DEPARTURE MODEL (FOR RESIDENTS)

—49 ORIGIN STATES

— STATE ATTRIBUTES

-POPULATION SUBGROUPS 
FIGURE 2. Attributes of states.

\author{
IMMIGRATION RATE \\ STATE AFDC \& FOOD STAMP BENEFITS
}

RACIAL SIMILARITY

TOTAL EMPLOYMENT GROWTH

MFG EMPLOYMENT GROWTH

SERVICE EMPLOYMENT GROWTH

PER CAPITA INCOME

UNEMPLOYMENT

COLD CLIMATE

HOT CLIMATE

ine precisely how these State attributes will affect the migration process for these primary labor force age categories. In addition, each model incorporates interactions with key population subgroups classed by race-ethnicity, gender, education attainment, and nativity. (See Figure 3.) The findings, described below, are the result of extensive preliminary analysis which investigated different combinations of State attributes, and their interactions with population subgroups. (Note: Both "first" and "best" estimates of each model are displayed below. $)^{2}$

${ }^{2}$ Preliminary analyses for these models involved investigating interactions between a range of relevant State origin or destination attributes and all relevant demographic sub-populations toward explaining resident rates of departure, and migrant patterns of destination selection. The original list of State attributes was more extensive than that listed in Figure 2 and included an assessment of State employment growth by industrial sector, and the State's violent crime rate. Similarly, a variety of interactions were employed with the population subgroups, made possible by the detailed census cross-tabulation at our disposal. These preliminary analyses took the form of cross-tabulations, and multivariate specifications.

The final results shown in Tables 5 and 7 include two models for each age group: "first" specification, and "best" specification. The "first" specification was arrived at after we had conducted our preliminary analyses and represents our tentative model, including the most important State attributes and their interactions with relevant population subgroups. The "best" specification involved rerunning this tentative model, including only those variables and interactions which showed greatest statistical significance. We present both versions of the model to point up the lack of significance associated with several factors (in the first specification) which were initially considered relevant on theoretical or policy grounds, and also showed promise in our preliminary analyses. 
W. FREY, K.-L. LIAW, Y. XIE, AND M. CARLSON

FIGURE 3. Key population subgroups (within poverty population).

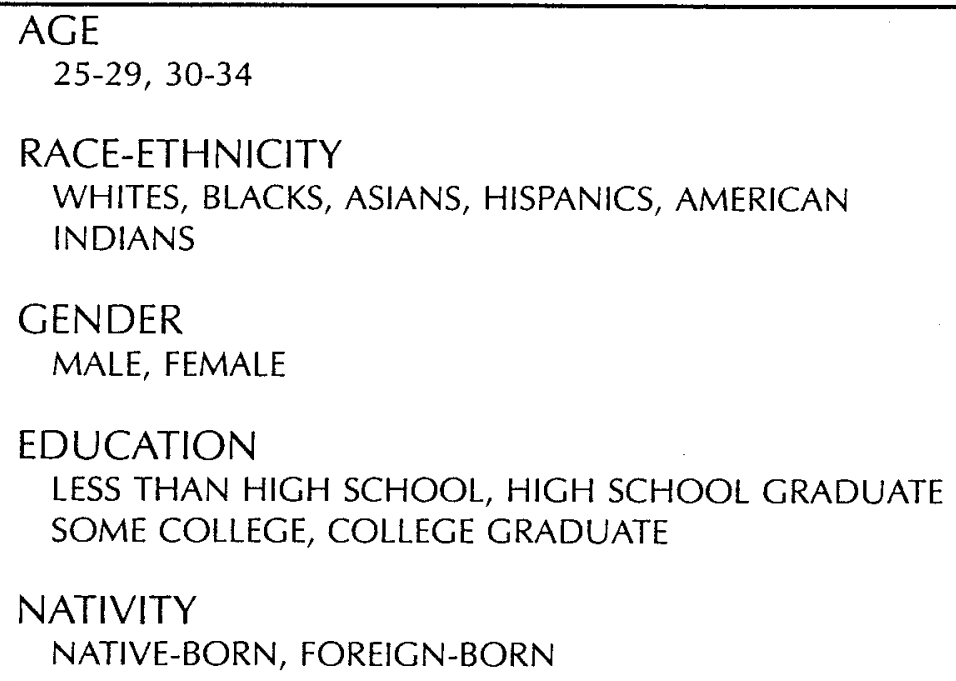

\section{Statistical Model}

For a particular subpopulation $\mathrm{t}$, let $\mathrm{p}_{\mathrm{i}} \mathrm{j}$, $\mathrm{t}$ denote the probability that the population living in state $i$ in 1985 had moved to state $j$ by 1990 . Although our theoretical interest centers on the determinants of $p_{i} j, t$, latent probability $p_{i} j, t$ is unobserved. Instead, our database contains population-specific out-migration rates, which can be viewed as sample-analog estimates of $p$ $\mathrm{i}, \mathrm{i}$. By the definitions of marginal and conditional probabilities, we conceptually decompose $\mathrm{p}_{\mathrm{i} j} \mathrm{j}, \mathrm{i}$ into

$$
p_{i j, t}=p_{i+, t} p_{j l i, t}
$$

where $p_{i}+, t$ is the marginal probability of departure from state $i$, and $p_{j} l i, t$ is the conditional probability of choosing state $j$ as the destination given departure from state $i$. In our nested logit model framework, we separately model $p_{i}+, t$ and $p_{j} l i, t$ and label them as the Departure Model and the Destination Model. First, for the sake of convenience, we will discuss the Destination Model and then the Departure Model. The Destination Model is essentially a logit specification with predictors that are population-specific as well as destination-specific. That is,

$$
p_{j l i, t}=\exp \left(\beta^{\prime} y_{i j, t}\right) / \sum_{k \neq i} \exp \left(\beta^{\prime} y_{i k, t}\right),
$$


where $y_{\mathrm{i}} \mathrm{j}, \mathrm{t}$ is a column vector of explanatory variables; $\beta^{\prime}$ is a row vector of unknown coefficients; and the summation in the denominator is over all possible destinations. With similar notations, we specify the Departure Model as

$$
\mathrm{p}_{\mathrm{i}+, \mathrm{t}}=\exp \left(\alpha^{\prime} \mathrm{x}_{\mathrm{i}, \mathrm{t}}\right) /\left[1+\exp \left(\alpha^{\prime} \mathrm{x}_{\mathrm{i}, \mathrm{t}}\right)\right],
$$

where $x_{i}, t$ is a column vector of explanatory variables including $l_{i}, t$, the natural logarithm of the denominator of the destination selection model:

$$
\mathrm{I}_{\mathrm{i}, \mathrm{t}}=\log \quad\left[\sum_{\mathrm{k} \neq \mathrm{i}} \exp \left(\beta^{\prime} y_{i k, t}\right)\right]
$$

$I_{i}, t$ is called the inclusive variable measuring the drawing power of the rest of the system on the potential migrant out of area i. $\alpha^{\prime}$ is a row vector of unknown coefficients.

The unknown parameters are to be estimated by the maximum quasilikelihood method (see Liaw \& Ledent, 1987). Unlike the least squares method, this method does not depend on the logarithms of the observed frequencies and hence is not constrained by many zero frequencies. As a consequence, the two analyses can incorporate migration streams across all 49 States (continental US, including District of Columbia).

\section{DESTINATION SELECTION PROCESS}

Because the model for the destination selection process is estimated before the departure process, we first present an inventory of the results of the Destination Choice Model (shown in Table 5), followed by a summary of the overall contributions to the total explanation for major factors in the model (Table 6). The model results, in Table 5, are useful because they point up significant interactions between State attributes and population subgroups. However, the contributions to explanation (Table 6) provide the best gauge as to the overall impacts State attributes exert on the destination selection of the migration process.

\section{Immigration}

To study the effects of foreign-born immigrants, our explanatory variable is the immigration rate of a State which is the potential destination for interstate migration. The immigration rate is defined by dividing the 1985-90 foreign-born immigrants of the State (aged 5 and over in 1990) by 


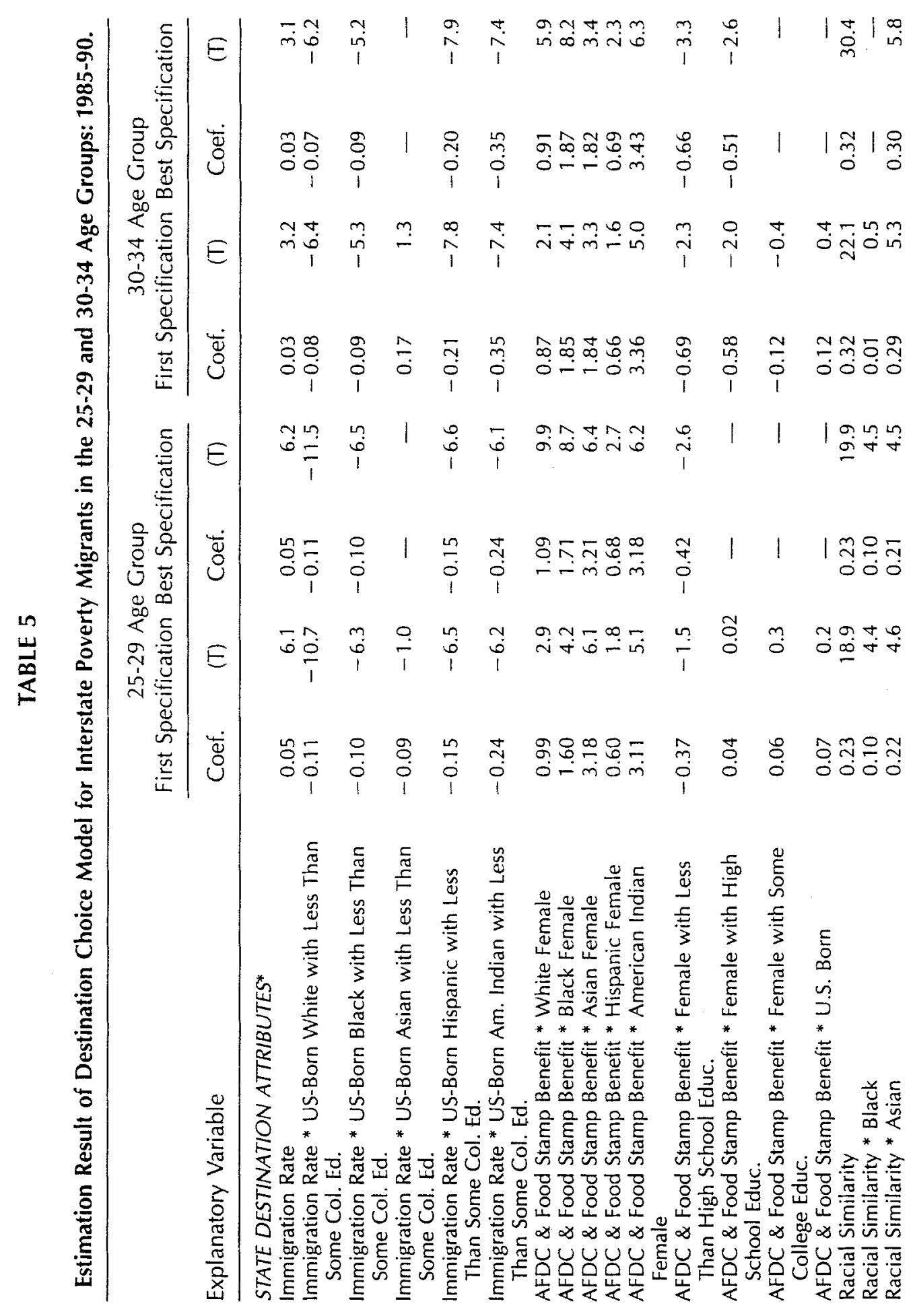




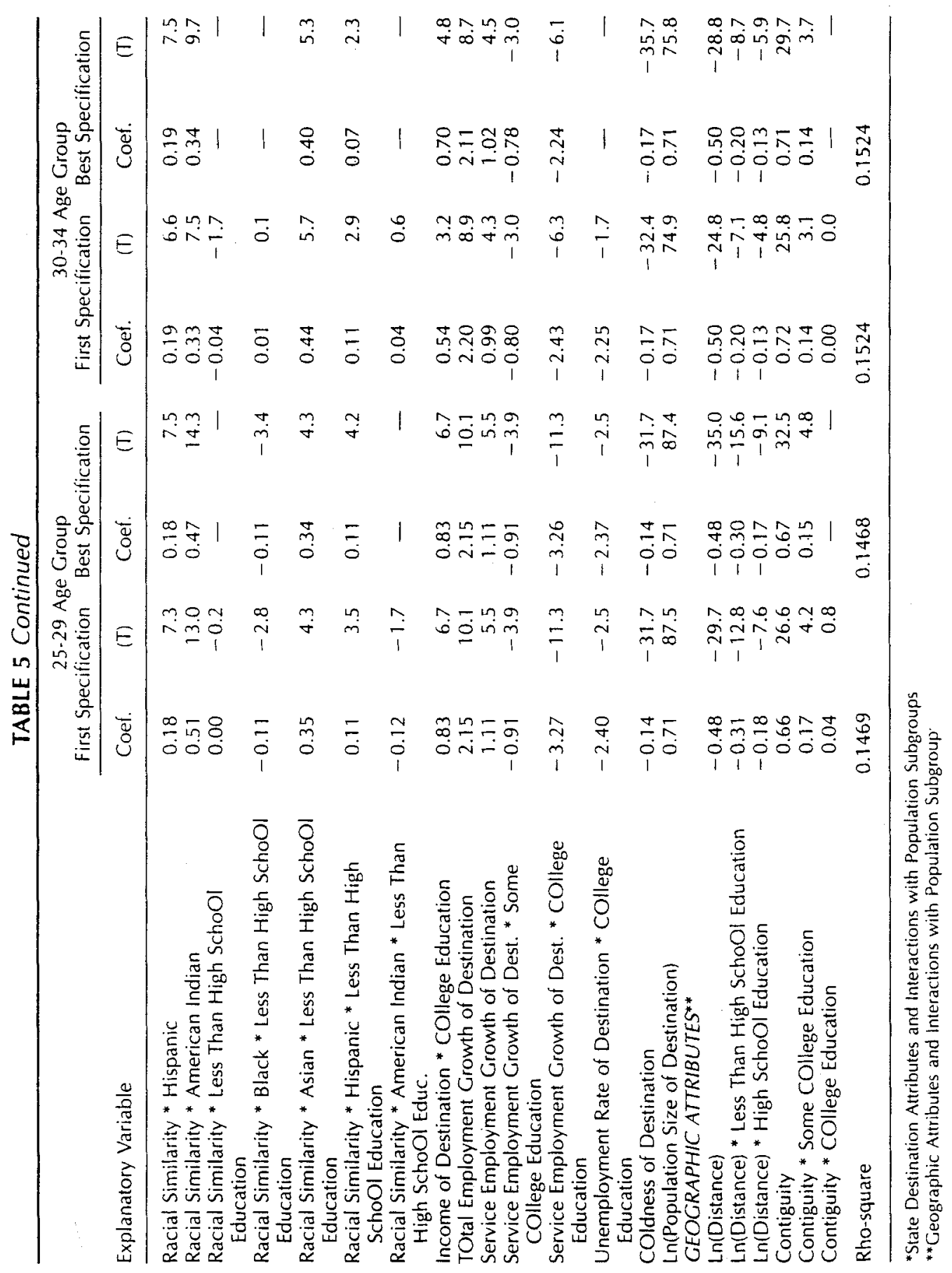




\section{TABLE 6}

\section{Effects of Deleting Selected Factors from the Best Destination Choice Model for Interstate Poverty Migrants in the 25-29 and 30-34 Age Groups}

\begin{tabular}{|c|c|c|c|}
\hline Deleted Explanatory Factor & Rho-square & $\begin{array}{l}\text { Decrease in } \\
\text { Rho-square }\end{array}$ & $\begin{array}{l}\text { Quasi Log } \\
\text { Likelihood }\end{array}$ \\
\hline & \multicolumn{3}{|c|}{ Ages 25-29 } \\
\hline Immigration & 0.1461 & 0.0007 & -1096941 \\
\hline AFDC \& Food Stamp Benefit & 0.1461 & 0.0008 & -1096978 \\
\hline Racial Similarity & 0.1365 & 0.0104 & -1109335 \\
\hline $\begin{array}{l}\text { Income, Employment Growth \& } \\
\text { Unemployment }\end{array}$ & 0.1447 & 0.0022 & -1098814 \\
\hline Coldness at Destination & 0.1433 & 0.0036 & -1100594 \\
\hline Population Size at Destination & 0.1138 & 0.0331 & -1138504 \\
\hline Distance & 0.1360 & 0.0108 & -1109927 \\
\hline Contiguity & 0.1416 & 0.0052 & -1102675 \\
\hline Distance \& Contiguity & 0.0879 & $\begin{array}{c}0.0589 \\
\text { Ages } 30-34\end{array}$ & -1171711 \\
\hline Immigration & 0.1516 & 0.0008 & -844249 \\
\hline AFDC \& Food Stamp Benefit & 0.1518 & 0.0006 & -844033 \\
\hline Racial Similarity & 0.1373 & 0.0151 & -858472 \\
\hline $\begin{array}{l}\text { Income, Employment Growth \& } \\
\text { Unemployment }\end{array}$ & 0.1504 & 0.0021 & -845519 \\
\hline Coldness at Destination & 0.1463 & 0.0061 & -849539 \\
\hline Population Size at Destination & 0.1200 & 0.0324 & -875680 \\
\hline Distance & 0.1422 & 0.0102 & -853644 \\
\hline Contiguity & 0.1465 & 0.0059 & -849305 \\
\hline Distance \& Contiguity & 0.0922 & 0.0602 & -903341 \\
\hline
\end{tabular}

Notes:

Statistics for Ages 25-29:

Quasi-Log Likelihood of Null Md! - $\quad-1284639$

Quasi-Log Likelihood of Best Mdl $\quad-1095997$

Rho-square of Best Model 0.1468

Statistics for Ages 30-34:

Quasi-Log Likelihood of Null Mdl $\quad$-995139

Quasi-Log Likelihood of Best Mdl $\quad-843477$

Rho-square of Best Model $\quad 0.1524$

the 1985 population size of the State (also aged 5 and over in 1990). The unit is percent per 5 years.

For the poor interstate migrants of both 25-29 and 30-34 age groups, the immigration rate had both positive and negative effects. The positive 
effect was found for migrants who were better educated (with at least some college education). The negative effect occurred to the U.S.-born less well educated (high school graduation or less) migrants. The negative effect of immigration on the destination choice propensities of the less well educated migrants occurred to all races, except for Asians. It was stronger for Hispanics and American Indians than for Non-Hispanic Whites and Blacks. With respect to Asians, the effect was statistically insignificant.

The negative effects for a State's immigration rate, interacting with the less well-educated segments of the migrant population, is consistent with the net migration patterns observed earlier. They suggest that at least part of the negative net internal migration for noncollege graduates in High Immigration States might be attributed to a reduced "pull." However, as our later results show, the increased "push" away from these States exerts a more dominant impact on the migration process.

\section{Welfare Benefits}

To study the potential attractions of welfare benefits to the poor interstate migrants, our explanatory variable is the real annual AFDC and food stamp benefit (AFDCFSB) per recipient family. The variable was created from the observed nominal values of the State in question for 1985 and 1988. The nominal values of the two years were first adjusted by the CPI to the 1992 dollar value. Then, the 1985 values of all States were adjusted by the 1985 State-specific cost of living indices (McMahon \& Chang, 1991). Due to data limitations, the 1989 cost of living indices were used to adjust the 1988 values. Finally, the real values were obtained by averaging the 1985 and 1988 adjusted values. The unit is $\$ 10,000$ per family.

We found that AFDCFSB had a positive (attractive) effect on the poor female migrants of all races. The positive effect was stronger on American Indians, Asians and Blacks than on Non-Hispanic Whites and Hispanics. With respect to education selectivity, we found that poor female interstate migrants with the lowest level of education were least likely to be attracted by AFDCFSB. It appears as if the least educated poor migrants were much less knowledgeable about interstate variation in social welfare, and intends to counter the stereotype that the least educated poor being drawn to "welfare magnets." Despite the significant interactions that are shown between State welfare benefits and select population subgroups, in Table 5, the overall contribution of these benefits in explaining the destination choices of poor migrants is minimal. This is discussed below in our review of the Table 6 results. 
W. FREY, K.-L. LIAW, Y. XIE, AND M. CARLSON

\section{Other State Attributes at Destination}

Racial Similarity. That the United States is a melting pot is more an ideal than a reality. We expect that interstate migrants are more prone to choose a destination with a familiar racial milieu. To capture this effect, our explanatory variable is racial similarity defined in the following way. For migrants of a given race, we first find the proportion of the 1985 population of a potential destination in question belonging to the same race, and then apply logit transformation to the proportion. For our analysis, we use five mutually exclusive racial categories: (1) Non-Hispanic White, (2) Black, (3) Asian (including Pacific Islander), (4) Hispanic, and (5) American Indian. For convenience, we call the last four categories the "minority races."

We found that racial similarity had highly significant positive effect on the destination choice propensities of the poor migrants of every race. In general, relative to the Non-Hispanic Whites, those belonging to the minority races were more strongly attracted by racial similarity. This was particularly true for poor American Indians and Asians.

To see if the least educated poor migrants were especially subject to the positive effect of racial similarity, we introduced into the destination choice model three-way interactions involving racial similarity, racial background, and the lowest level of education (less than high school graduation).

The interaction terms showed that the low education status significantly strengthened the propensities of Asian and Hispanic poor migrants to select destinations with a higher concentration of the corresponding minorities. However, in the 30-34 age group, Black high school dropouts were found to be significantly less attracted by racial similarity than their better educated counterparts.

Labor Market Variables. Our analysis employs the conventional labor market variables: (1) income per capita, (2) employment growth rate, and (3) unemployment rate of potential destination.

For a State as a potential destination, income (per capita) is defined in the following way. We first adjust the 1985 and 1989 nominal per capita incomes of the State by the corresponding cost of living indices of the same years (MCMahon \& Chang, 1991). The 1985 and 1989 adjusted values are then averaged. The unit is $\$ 10,000$ per person.

We found that for poor migrants, the expected positive effect of destination income only occurred to those with the highest (college) level of education. 
As proxies for the employment opportunities at potential destination, we use two measures of employment growth: total employment growth rate and service employment growth rate. Both variables are computed by dividing the 1985-1989 employment growth by the 1985 employment size. The unit is "proportion per 4 years."

We found that poor migrants were clearly subject to the pull of total employment growth rate at potential destination. However, the pull of service employment growth was limited to the less well educated (less than some college education) poor migrants. Those with college education were practically unaffected by the pull of service employment growth. It seems that the "pull effects" of service employment growth in the late 1980s was mostly limited to the low-skill jobs that did not need college level education.

We use unemployment rate as a proxy for the difficulty in finding and holding a job. Since we believe that among the conventional labor market variables, unemployment rate is most likely to be affected by the feedback effect of immigration, our unemployment rate is the 1985 unemployment rate (rather than the average of the 1985 and 1989 unemployment rates).

We found that among poor migrants, only those with college education were subject to the negative effect of the unemployment rate at potential destination. For the 25-29 age group, this negative effect was not even statistically significant.

Our overall impression about the effects of the conventional labor market variables is that the destination choice behaviors were more likely to result in the improvement of incomes and employment for better educated poor migrants. Their less educated counterparts, being mainly attracted by destinations with low-quality jobs, were less likely to improve their economic situation with migration.

Climate. We use the coldness of winter to represent the poorness of climate at potential destination. The coldness of a State is defined as weighted average of the heating degree-days of cities with records from 1951 to 1980 , using city populations as the weights. The unit is 1000 degree(F)-days.

We found that coldness at destination had a highly significant negative effect on the destination choice propensities of the poor migrants. The negative effect was somewhat stronger for the 30-34 age group than for the 25-29 age group.

Population Size. The size effect of potential destination is represented by the natural log of its population. As expected, this variable has a highly significant positive effect on the destination choice propensities of the poor migrants. 
W. FREY, K.-L. LIAW, Y. XIE, AND M. CARLSON

\section{Geographic Attributes}

The Destination Selection Model also includes two geographic attributes, Distance Decay, and Contiguity, which represent aspects of geographic structure known to affect the destination selection process of migrants. Their effects, and interactions with key population subgroups, are discussed below.

Distance Decay. To study the negative effect of distance, our explanatory variable is the natural log of the weighted distance between State population centers. The unit is "log of miles."

We found that distance had a highly significant negative effect, and that the effect was the strongest for the least educated. The effect was also stronger for the high school graduates than for those with at least some college education.

Contiguity. We expect that migrants are more prone to select a neighboring State, because in addition to having a short distance, the neighboring State functions as an "intervening opportunity" for migrants who could have gone to a non-adjacent State. To capture the effect of intervening opportunity, our explanatory variable is contiguity which is a dummy variable assuming the value of 1 when the potential destination shares a common border with the origin.

We found that the positive effect of contiguity was highly significant for the poor migrants. We also found that the contiguity effect is somewhat stronger for those with some college education, suggesting that those with better education were more likely to participate in "interstate suburbanization" (e.g., the migration from New York and Philadelphia metropolitan centers to their suburban areas in New Jersey).

\section{Relative Importance of Immigration and Welfare Benefits}

As indicated earlier, our evaluations of State attribute contributions to the total explanation of destination selection provides the best assessment of their overall impacts on this part of the migration process. To evaluate the relative importance of an explanatory factor, we delete the factor from the "best" specification and observe the resulting decrease in the model's explanatory power (Rho-square): the greater the decrease in Rho-square, the more important the deleted factor (see Table 6).

The findings show clearly that both immigration and welfare benefits were much less important than the set of conventional labor market variables in affecting the destination choice behaviors of poor migrants. The 
negative effect of cold winter was greater than the combined effects of the conventional labor market variables. However, the effect of racial similarity was much greater than any of these factors. Spatial proximity (represented by both distance and contiguity) and, to a lesser extent, destination population size were by far the most important explanatory factors. However, these latter factors might be thought of as geographic "controls." An important conclusion from these comparisons is that neither immigration nor welfare benefits affect the destination choice process nearly as much as racial similarity or the labor market variables.

\section{DEPARTURE PROCESS}

This section discusses the results of the Departure Model, representing the "push" effects of the various State attributes and their interactions with key population subgroups. We summarize the most important aspects of the Model, as shown in Table 7. We then discuss the overall impact of our two policy factors, and other State attributes, in contributing to the overall explanation of the Model (shown in Table 8).

\section{Immigration}

In the Departure Model, we found that the immigration rate of the State of origin had significantly positive (repulsive) effects on Whites, Blacks, Hispanics and American Indians, but significantly negative effects on Asians.

For some races, the effects of foreign-born immigrants turned out to be selective with respect to the level of education. For Whites, the repulsive effect of immigration was particular strong on those who were least educated (less than high school education). By contrast, among Blacks, the least educated turned out to be less affected than their better educated counterparts by the repulsive effect of immigration. For Asians, the complementary effect of immigration was reduced to near zero in the 30-34 age group, and was turned to a repulsive effect in the 25-29 age group. Nonetheless, when viewed in concert with immigration's overall effect on migrant departure (discussed below), these results indicate that poor less-educated internal migrants are affected by a strong "push" associated with immigration.

\section{Welfare Benefits}

Do welfare benefits interact with gender in their effects on State migrant departures? With the exception of Whites, some confirmatory evi- 


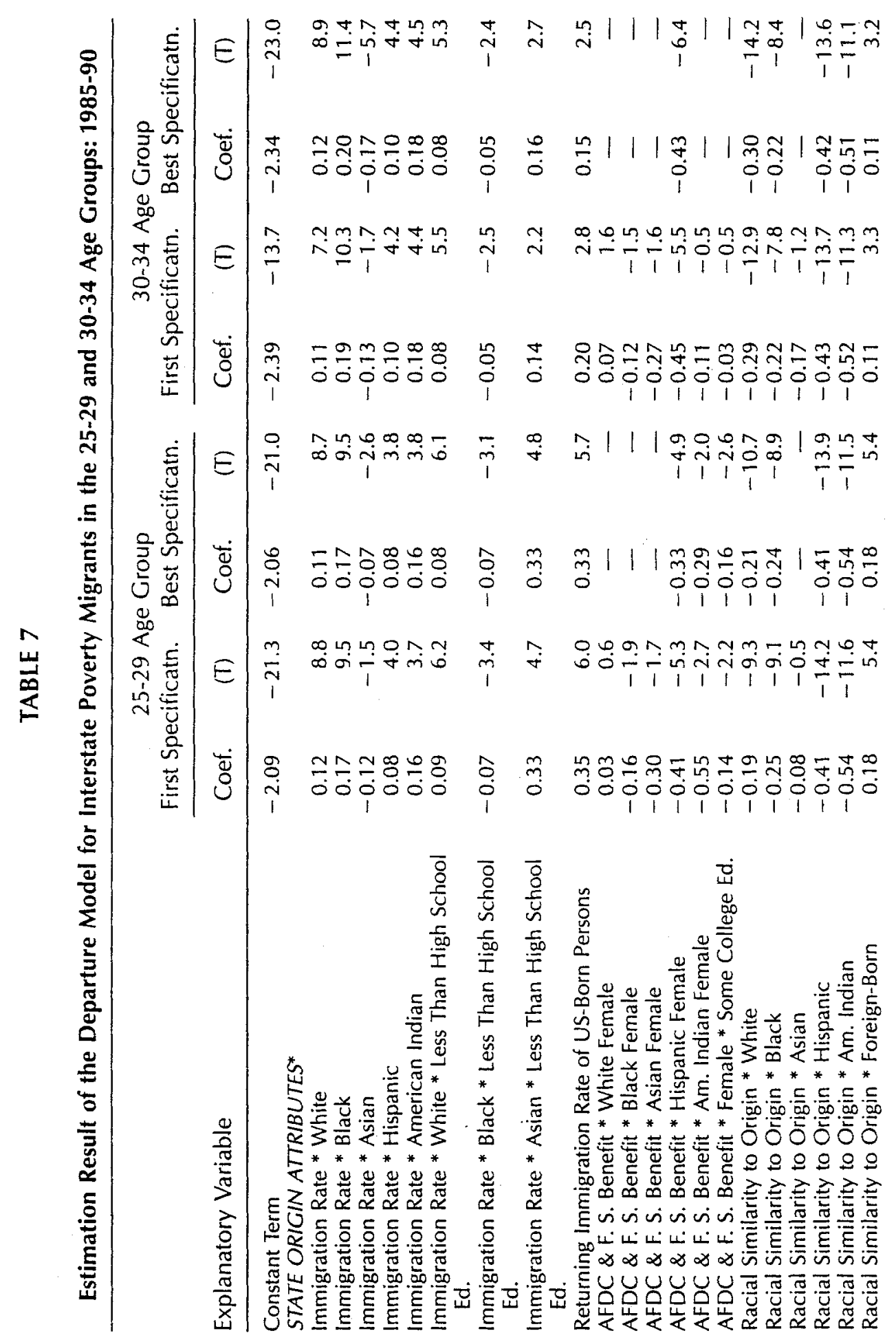




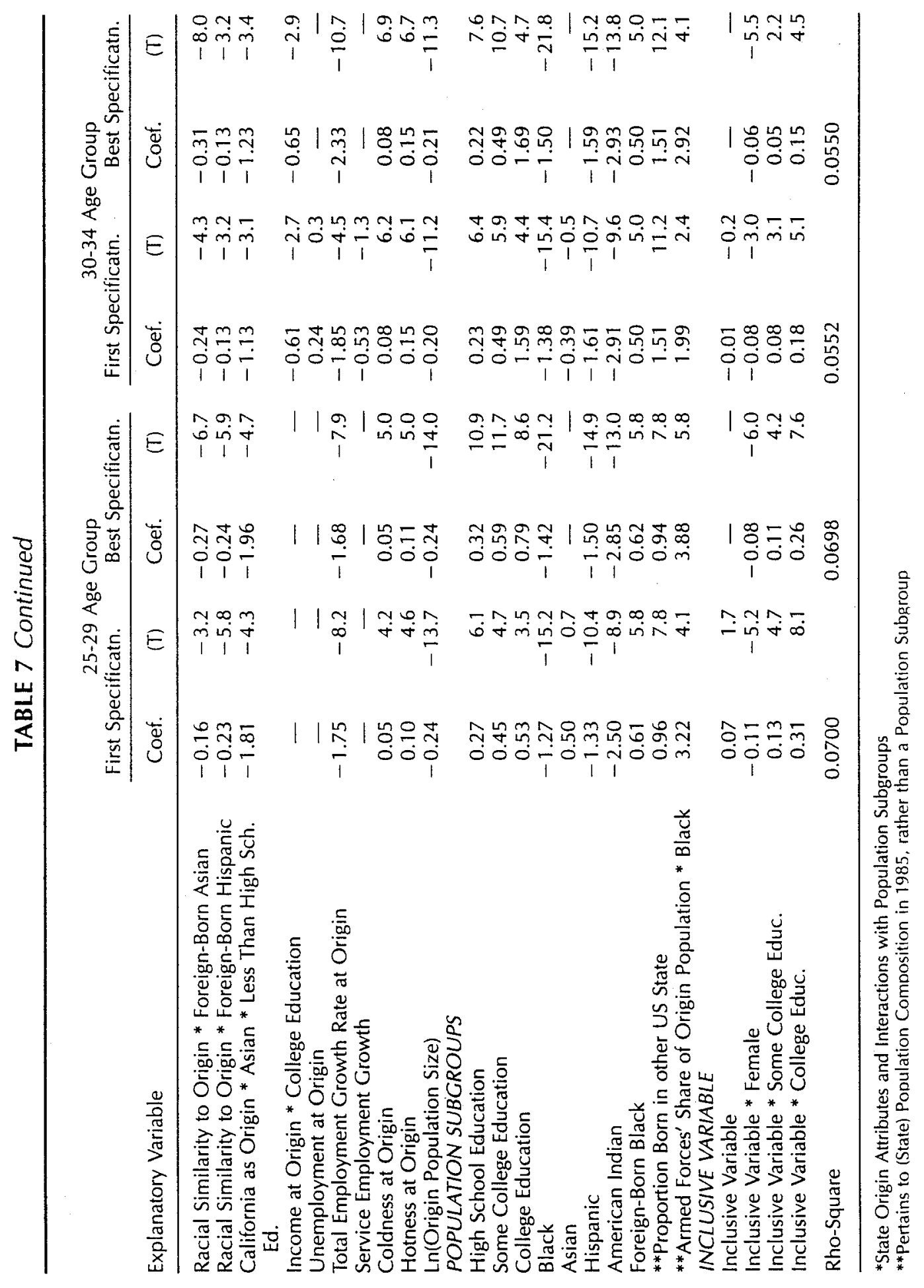


W. FREY, K.-L. LIAW, Y. XIE, AND M. CARLSON

\section{TABLE 8}

Effects of Selected Factors from the Best Departure Choice Model for Interstate Poverty Migrants in the 25-29 and 30-34 Age Groups

\begin{tabular}{lccc}
\hline Deleted Explanatory Factor & Rho-square & $\begin{array}{c}\text { Decrease in } \\
\text { Rho-square }\end{array}$ & $\begin{array}{l}\text { Quasi Log } \\
\text { Likelihood }\end{array}$ \\
& & Ages 25-29 \\
Immigration & 0.0671 & 0.0027 & -887425 \\
AFDC \& Food Stamp Benefit & 0.0694 & 0.0004 & -885293 \\
Racial Similarity & 0.0626 & 0.0072 & -891749 \\
Income, Employment Growth \& & 0.0692 & 0.0006 & -885453 \\
$\quad$ Unemployment at Origin & & & \\
Coldness \& Hotness at Origin & 0.0695 & 0.0003 & -885137 \\
Population Size at Origin & 0.0679 & 0.0019 & -886672 \\
Education (population subgroups) & 0.0586 & 0.0112 & -895549 \\
Inclusive Variable & 0.0691 & 0.0007 & -885568 \\
& & $A g e s 30-34$ & \\
Immigration & 0.0514 & 0.0035 & -754279 \\
AFDC \& Food Stamp Benefit & 0.0546 & 0.0004 & -751789 \\
Racial Similarity & 0.0453 & 0.0097 & -759148 \\
Income, Employment Growth \& & 0.0538 & 0.0012 & -752433 \\
$\quad$ Unemployment at Origin & & & \\
Coldness \& Hotness at Origin & 0.0535 & 0.0015 & -752637 \\
Population Size at Origin & 0.0537 & 0.0013 & -752490 \\
Education (population subgroups) & 0.0586 & 0.0112 & -895549 \\
Inclusive Variable & 0.0546 & 0.0004 & -751776 \\
\hline
\end{tabular}

Notes:

Statistics for Ages 25-29:

Quasi-Log Likelihood of Null Mdl $\quad-951299$

Quasi-Log Likelihood of Best Mdl $\quad-884879$

Rho-square of Best Model $\quad 0.0698$

Statistics for Ages 30-34:

Quasi-Log Likelihood of Null Mdl $\quad-795177$

Quasi-Log Likelihood of Best Mdl $\quad-751464$

Rho-square of Best Model $\quad 0.0550$

dence is provided in Table 7. However, only for poor female Hispanics was the negative (retention) effect of AFDCFSB significant in both 25-29 and 30-34 age groups. In the 25-29 age group, the negative effect of AFDCFSB was also significant on the poor female American Indians. We found very little evidence that the retention effect of AFDCFSB was selective with respect to education. In the 25-29 age group, poor females with some college education were shown to be somewhat more subject to this retention 
POPULATION AND ENVIRONMENT

effect. While informative, these findings are put into broader perspective in our analyses (below) which show that State welfare benefits at origin contribute little to the overall explanation to the departure of poor migrants.

\section{Other State Attributes of Origin}

Racial Similarity. Except for Asians, the poor adults of every race were subject to the retention effect of racial similarity to the origin population. This retention effect was particularly strong on Hispanics and American Indians. For Asians, the retention effect is not significantly different from zero.

With respect to place of birth, the retention effect of racial similarity to origin population in general was weaker for the foreign-borns than for the U.S.-borns, except for those with Asian or Hispanic background. However, for Asians and Hispanics, this difference by place of birth was either relatively weak or even reversed.

We also found that the least educated Asians were particularly subject to the retention effect of California. A probable reason for this is the relative proximity of California to Asian countries.

Labor Market Variables. The income level at origin turned out to have very limited retention effect. This effect was significant only on the best-educated poor in the 30-34 age group. With respect to employment opportunities, the retention effect was relatively general and clear. We found that in both 25-29 and 30-34 age groups, the poor were subject to a strong retention effect of the total employment growth at origin. However, the service employment growth at origin as an additional separate component did not show any significant retention effect. With respect to the unemployment rate at origin, we found that it did not have any repulsive effect on the poor adults.

Climate. For each origin State, in addition to the coldness of winter, we also use as an explanatory variable the hotness of summer (in 1000 cooling degree-days). This variable is also computed as a weighted average of the annual data of cities with records from 1951 to 1980 .

We found that both coldness and hotness had significant positive (repulsive) effects on the poor adults.

Population Size at Origin. We use the natural log of the origin population size to represent the size effect. In light of the huge interstate variation in population size, it is not surprising that this variable had a highly significant negative (retention) effect. 
W. FREY, K.-L. LIAW, Y. XIE, AND M. CARLSON

\section{Population Subgroups}

Education. In both 25-29 and 30-34 age groups, we found that the higher the level of eduction, the higher the departure propensities, when other variables are controlled.

Minority Races. Except for Asians, the poor belonging to minority races had lower departure propensities than their Non-Hispanic White counterparts. This was especially true for American Indians. While this is also true among Blacks, foreign-born Blacks were more migratory than the U.S.-born. In terms of departure propensities, Asians were not significantly different from Whites.

Other Population Effects. Two other State attributes are included in the analysis as "compositional" variables: Person Born in Other States, and Armed Forces Share of Origin Population. The first variable is motivated by earlier migration studies that show the residents, who are not born in a State, are most prone to move out (Long, 1988). The second variable is motivated by similar considerations in that Armed Forces personnel may be resident in the State over a transitory period. Unlike the other Population Subgroup variables, which pertain to disaggregations of the study population, these two attributes pertain to the origin State's composition in 1985. The Proportion Born in the State exhibits a significant positive effect on departure rates for both 25-29 and 30-34 age groups. The Armed Forces' share of Origin Population is significant only when interacted with the Black subpopulation.

\section{Drawing Effects of Inclusive Variable}

The inclusive variable represents the perceived attractiveness of the rest of the United States associated with the Destination Choice Model and should exert a positive (drawing) effect on the departure propensities. However, because its explanatory power overlaps substantially with that of the education factor, its positive effect in the best specification of the departure model can only be revealed for those with at least some college education. For females with less than some college education, we found the curious result that the States with higher inclusive values turned out to have a lower departure rate.

When the education factor is removed from the departure model, the inclusive variable turned out to have a theoretically meaningful coefficient (0.2391) and a large t-ratio (22.3), implying that the States that were more 
POPULATION AND ENVIRONMENT

accessible to attractive destination were more likely to have higher departure rates.

\section{Relative Importance of Immigration and Welfare Benefits}

As in our evaluation of the Destination Choice process, our overall assessment of State attributes in explaining the departure process will rely on the relative contributions of each factor to the overall explanation (see Table 8). Again, the importance of a factor in the Departure Model is evaluated by the decrease in Rho-square due to its deletion from the best specification: the greater the decrease, the more important the deleted factor.

We found that the retention effect of State Welfare Benefits (AFDCFSB) was much less important than the effects of most other factors, whereas the repulsive effect of foreign immigration was more important than the combined effect of the conventional labor market variables. This is a significant finding and suggests that the strong immigration effect on net internal migration of the poor is attributable primarily to its "push" effects. Also significant is the strong effect that racial similarity exerts in retaining migrants in States with similar racial profiles. Still, when this effect is controlled, our findings show that high immigration increases the departure of Whites, Blacks and other non-Asian minorities.

Compared with other factors, the inclusive variable played a relatively minor role in the departure model. In other words, the variation in departure rates did not depend strongly on the variation in the drawing power from the rest of the country. This is consistent with an earlier observation (based on Map 1) that poverty migration responds largely to "push" effects at origin, and is directed to a fairly diffuse array of destinations.

\section{CONCLUSION}

This study has analyzed detailed 1990 census migration data to assess the impact of two policy-alterable State attributes-immigration levels and State welfare benefits-for the inter-State migration of the nation's poverty population. In our descriptive analyses of net migration trends and correlates, as well as our more in-depth investigation of the migration process, our results are fairly clear. High levels of immigration to selected US States does affect a selective out-migration of the poverty population, when other relevant factors are taken into account. This impact tends to be stronger for Whites, Blacks, and other non-Asian minorities as well as for the least educated. These results are consistent with arguments that internal migrants 
are responding to labor market competition from similarly educated immigrants. ${ }^{3}$ This phenomenon may account for the small displacement effects observed in studies which examine the labor displacement impacts of immigrants on the native population but do not take selective native outmigration into account (Borjas, 1994; Martin \& Midgely, 1994). Immigration's impact on the internal migration process acts as a stronger "push" toward increasing the out-migration of the resident poor, than as a reduced "pull" to discourage further poverty in-migration from other States.

Our results were equally as clear in assessing the effects of State welfare benefits on internal migration of the poverty population, by showing these effects to be very small. Although our early descriptive analysis (in Table 1) showed that High Welfare Benefit States had greater rates of net in-migration for the poverty population than for the nonpoverty population, our multivariate analysis indicates that this is not attributable to welfare benefits per se when other relevant factors are taken into account. Moreover, our analysis of the migration process shows that State welfare benefits exert similarly small effects on both the departure and destination selection of inter-State poverty migrants.

The importance of immigration for the redistribution of poverty population, therefore, has both direct and indirect effects. While this paper has examined the indirect effects of immigration, as it precipitates a secondary internal migration across States, the direct contribution of immigration to State poverty gains are substantial. As Table 9 shows, three of the top four States gaining in poverty migration (from all migration sources)-California, Texas, and New York-achieve these gains from immigration alone. Over the 1985-90 period, 34 States received more poor migrants from immigration than they did from net internal migration. However, the impact of immigration is particularly heavy in the High Immigration States as is evidenced from the "turnover" in poverty population for California (Table 10). This dynamic is noteworthy since the immigrant population appears to rely just as much on welfare benefits as the native-born (Borjas, 1994; The New York Times, 1995).

${ }^{3}$ These findings are also consistent with other explanations linking immigration to a net out-migration of longer-term and native-born US residents. In addition to labor market competition, immigrants may also exert indirect pressure via increased taxes and social expenditures on an area's residents, or by posing competition in the housing market. Some of the outmovement, especially that selective on race, may reflect the kinds of tastes or prejudices on a broader geographic scale that had previously motivated white suburban flight (Frey, 1994a). It is not possible with the present research to disentangle these motivations for the observed net out-migration. However, the demographic selectivity associated with the out-migration response to immigration, as documented here, is consistent with what would be expected under conditions of labor market competition with low-skilled immigrants (Borjas, 1994). 


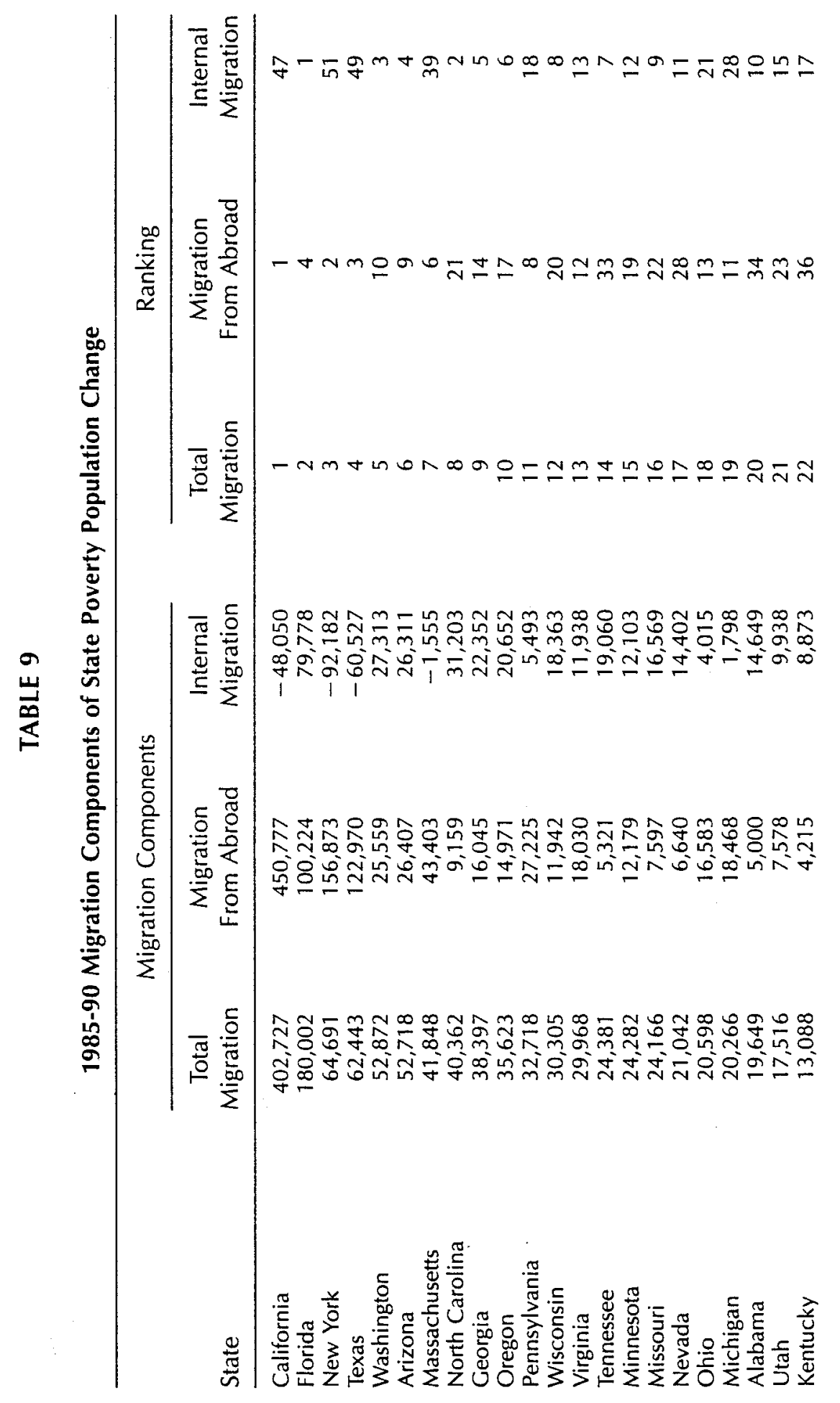




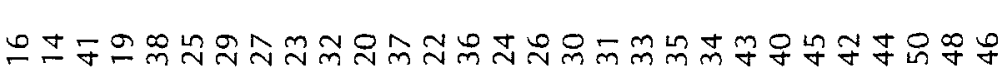

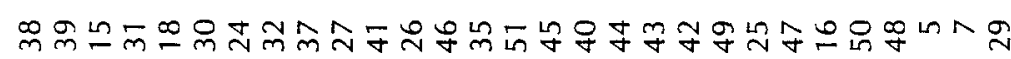

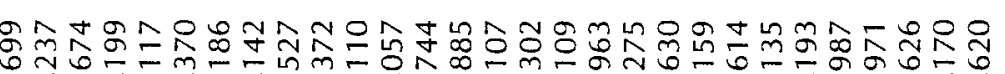

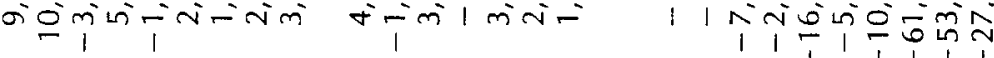

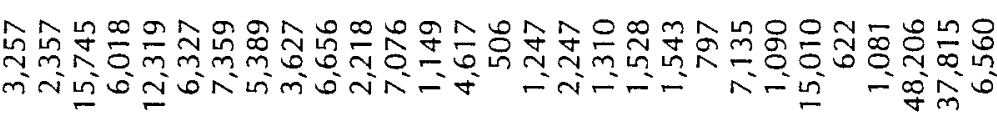

$\stackrel{1}{8}$

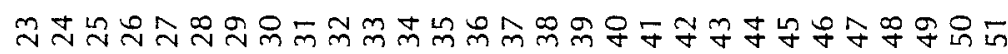


TABLE 10

Immigration and Internal Migration Components for California's Poverty Population

\begin{tabular}{|c|c|c|c|c|}
\hline \multirow[b]{2}{*}{$\begin{array}{l}\text { Demographic } \\
\text { Categories }\end{array}$} & \multicolumn{2}{|c|}{$\begin{array}{c}\text { 1985-90 Migration } \\
\text { Components }\end{array}$} & \multicolumn{2}{|c|}{ Rates per 1990 Population } \\
\hline & $\begin{array}{l}\text { Immigration } \\
\text { from Abroad }\end{array}$ & $\begin{array}{l}\text { Net Internal } \\
\text { Migration }\end{array}$ & $\begin{array}{l}\text { Immigration } \\
\text { from Abroad }\end{array}$ & $\begin{array}{l}\text { Net Internal } \\
\text { Migration }\end{array}$ \\
\hline Total* & 450,777 & $-48,050$ & 14.1 & -1.5 \\
\hline \multicolumn{5}{|l|}{ Race-Ethnicity* } \\
\hline Whites & 58,588 & $-42,575$ & 5.4 & -3.9 \\
\hline Blacks & 6,836 & $-6,522$ & 1.8 & -1.8 \\
\hline Latinos & 276,479 & $-15,040$ & 20.2 & -1.1 \\
\hline Asians & 108,874 & 16,117 & 30.2 & 4.5 \\
\hline \multicolumn{5}{|l|}{ Gender* } \\
\hline Males & 230,861 & $-22,379$ & 15.9 & -1.5 \\
\hline Females & 219,916 & $-25,671$ & 12.6 & -1.5 \\
\hline \multicolumn{5}{|l|}{ Education $^{* *}$} \\
\hline Less than High School & 117,672 & $-10,733$ & 14.4 & -1.3 \\
\hline High School Graduates & 30,673 & $-13,988$ & 8.7 & -4.0 \\
\hline Some College & 27,055 & $-12,536$ & 8.3 & -3.8 \\
\hline College Graduates & 29,428 & -368 & 19.5 & -0.2 \\
\hline \multicolumn{5}{|l|}{ Age } \\
\hline $5-14$ & 81,689 & $-11,693$ & 11.0 & -1.6 \\
\hline $15-24$ & 164,260 & 1,268 & 20.7 & 0.2 \\
\hline $25-34$ & 112,649 & $-12,822$ & 17.1 & -2.0 \\
\hline $35-44$ & 47,505 & $-9,340$ & 11.7 & -2.3 \\
\hline $45-54$ & 22,056 & -4.790 & 11.0 & -2.4 \\
\hline $55-64$ & 12,775 & $-5,276$ & 8.0 & -3.3 \\
\hline $65+$ & 9,843 & $-5,397$ & 4.3 & -2.4 \\
\hline
\end{tabular}

*Ages 5 and above in 1990

**Ages 25 and above in 1990

The immigration gains and internal migration losses for these States' poverty populations not only increase their numbers of poor but change their characteristics. The poor populations of these States will become increasingly Hispanic and Asian, with lower educations and younger age structures. The fact that net out-migration of the resident poor selects on somewhat comparable characteristics, except for race, suggests that increasingly sharp demographic divisions by income class will exist within these high immigration areas (Frey, 1995b). Moreover, the importance of a State's racial and ethnic similarity as both a "pull" and reduced "push" for poverty migration suggests the possibility of greater cross-State divisions in poverty populations, by race and ethnicity. This would be consistent with 
W. FREY, K.-L. LIAW, Y. XIE, AND M. CARLSON

the larger demographic balkanization which appears to be emerging across US States and metropolitan areas (Frey, 1995a), associated with widening spatial distinctions by race and class.

\section{REFERENCES}

Barringer, Herbert R., Gardner, Robert W., \& Levin, Michael J. (1993). Asians and Pacific Islanders in the United States. A 1980 Census Monograph. New York: Russell Sage.

Blank, Rebecca M. (1988). The effect of welfare and wage levels on the location decisions of female-headed households. Journal of Urban Economics 24, 186-211.

Borjas, George J. (1992). National origin and the skills of immigrants in the post-war period. In George J. Borjas and Richard Freeman (Eds.). Immigration and the work force. Chicago: University of Chicago Press.

Borjas, George J. (1994). The economics of immigration. Journal of Economic Literature 32 (December 1994), 1667-1717.

Cebula, Richard J. (1979). A survey of the literature on the migration-impact of state and local policies. Public Finance 34, (1), 39-84.

Cebula, Richard J. \& Belton, Willie J. (1994). Voting with one's feet: An empirical analysis of public welfare and migration of the American Indian, 1985-1990. American Journal of Economics and Sociology 53(3), 273-280.

Clark, Rebecca. (1991). Does welfare affect migration? Washington, DC: The Urban Institute.

Cushing, Brian J. (1993). The effect of the social welfare system on metropolitan migration in the U.S., by income group, gender and family structure. Urban Studies 30(2), 325-338.

Filer, Randall K. (1992). The effect of immigrant arrivals on migratory patterns of native workers. In George J. Borjas and Richard B. Freeman (Eds.). Immigration and the work force pp. 245-269. National Bureau of Economic Research. Chicago: University of Chicago Press.

Fix, Michael \& Passel, Jeffrey. (1994). Immigration and immigrants' setting the record straight. Washington, DC: The Urban Institute.

Frey, William H. (1979). The changing impact of white migration on the population compositions of origin and destination metropolitan areas. Demography 16(2), 219-238.

Frey, William H. (1994a). The new white flight. American Demographics (April), 40-48.

Frey, William H. (1994b). Immigration and internal migration for US states: 1990 census findings by poverty status and race. Research Report No. 94-320. Ann Arbor, M1: Population Studies Center, University of Michigan.

Frey, William H. (1995a). The new geography of US population shifts: Trends toward balkanization. In Reynolds Farley (Ed.). The State of the Union: Social Trends pp. 271-336. New York: Russell Sage.

Frey, William H. (1995b). Immigration and internal migration 'flight': A California case study. Population and Environment 16, 4(March) 353-375

Frey, William H. (1995c). Immigration and internal migration 'flight' from US metro areas: Toward a new demographic balkanisation. Urban Studies 32(May):733-757.

Frey, William H. \& Speare, Alden, Jr. (1988). Regional and metropolitan growth and decline in the United States. A 1980 Census Monograph. New York: Russell Sage.

Gramlich, Edward M. \& Laren, Deborah S.. (1984). Migration and income redistribution responsibilities. Journal of Human Resources 19, 489-511.

Hanson, Russell L. \& Hartman, John T. (1994). Do welfare magnets attract? Institute for Research on Poverty discussion Paper no. 1028-94, University of Wisconsin-Madison.

Johnson, James H., Jr. \& Roseman, Curtis. (1990). Increasing black outmigration from Los Angeles. The role of household dynamics and kinship systems. Annals of the American Association of American Geographers 80(2), 205-222. 


\section{POPULATION AND ENVIRONMENT}

Liaw, Kao-Lee. (1990). Joint effects of personal factors and ecological variables on the interprovincial migration pattern of young adults in Canada: A nested logit analysis. Geographical Analysis 22(3), 189-208.

Liaw, Kao Lee \& Barteis, Cornelius. (1982). Estimation and interpretation of a nonlinear migration model. Geographical Analysis 14, 229-245.

Liaw, Kao Lee \& Ledent, Jacques. (1988). Joint effects of personal and ecological factors on elderly interprovincial migration in Canada. Canadian Journal of Regional Science 11, $77-100$.

Liaw, Kao Lee \& Ledent, Jacques. (1987). Nested logit model and maximum quasi likelihood method: A flexible methodology for analyzing interregional migration patterns. Regional Science and Urban Economics 17, 67-88.

Liaw, Kao Lee \& Ottomo, A. (1991). Inter-prefectoral migration patterns of young adults in Japan: An explanation using a nested logit model. Journal of Population Studies (Japan), $14,1-20$.

Long, Larry. (1988). Migration and residential mobility in the United States. A 1980 Census Monograph. New York: Russell Sage.

Martin, Philip \& Midgley, Elizabeth. (1994). Immigration to the United States: Journey to an uncertain destination. Population Bulletin 49, (2). Washington, DC: Population Reference Bureau.

Martin, Susan Forbes. (1993). The commission on immigration reform. Migration World, Vol. $X X I,(22 / 3), 43-44$

MacMahon, Waiter W. \& Chang, Shao-Chung. (1991). Geographical cost of living differences: Interstate and intrastate update 1991. MacArthur/Spencer Series Number 20. Illinois State University: Center for the Study of Educational Finance.

McHugh, Kevin E. (1987). Black migration reversal in the United States. Geographical Review $77,171-187$.

McHugh, Kevin E. (1989). Hispanic migration and population redistribution in the United States. Professional Geographer 41(4), 429-439.

Moffitt, Robert. (1992). Incentive effects of the US welfare system. Journal of Economic Literature 30(1), 1.61.

The New York Times. (1993). Florida wants US aid for immigrants, December 21, p. A7.

The New York Times. (1994). The unfair immigration burden, January 11, p. A14

The New York Times. (1995). For elderly immigrants, a retirement plan in the US, April 16, 1995, p. A1.

Peterson, Paul E. \& Rom, Mark C. (1990). Welfare magnets. Washington, DC: The Brookings Institution.

Schram, Sanford F. \& Krueger, Gary. (1994). Interstate variation in welfare benefits and the migration of the poor: Substantive concerns and symbolic responses. Institute for Research on Poverty Discussion Paper no. 1032-94, University of Wisconsin-Madison.

Southwick, Lawrence, Jr. (1981). Public welfare programs and recipient migration. Growth and Change (October), 22-32.

Voss, Paul R., Corbett, Thomas \& Randell, Richard. (1992). Interstate migration and public welfare: The migration decision-making of a low income population. In Patrick $C$. Jobes, William F. Stinner \& John M. Wardwell (Eds.). Community, Society and Migration: Non-economic Migration in America, pp. 111-147. Lanham, MD: University Press of America.

Walker, Robert, Ellis, Mark \& Barff, Richard. (1992). Linked migration systems: Immigration and internal labor flows in the United States. Economic Geography 68, 234-248.

Walker, James R. (1994). Migration among low-income households: Helping the witch doctors reach consensus. Institute for Research on Poverty Discussion Paper no. 1031-94, University of Wisconsin-Madison.

The Washington Post. (1993). Poor Americans are seen fleeing some states as immigrants move in, September 12, p. A3.

White, Michael j. \& Hunter, Lori. (1993). The migratory response of native-born workers to 
W. FREY, K.-L. LIAW, Y. XIE, AND M. CARLSON

the presence of immigrants in the labor market. Presented at 1993 Meetings of the Population Association of America, Cincinnati (April).

Xie, Yu. (1989). An alternative purging method: Controlling the composition-dependent interaction in an analysis of rates. Demography 26, 711-716.

Xie, Yu. (1992). The log-multiplicative layer model for comparing mobility tables. American Sociological Review, 57 (3), 380-395. 

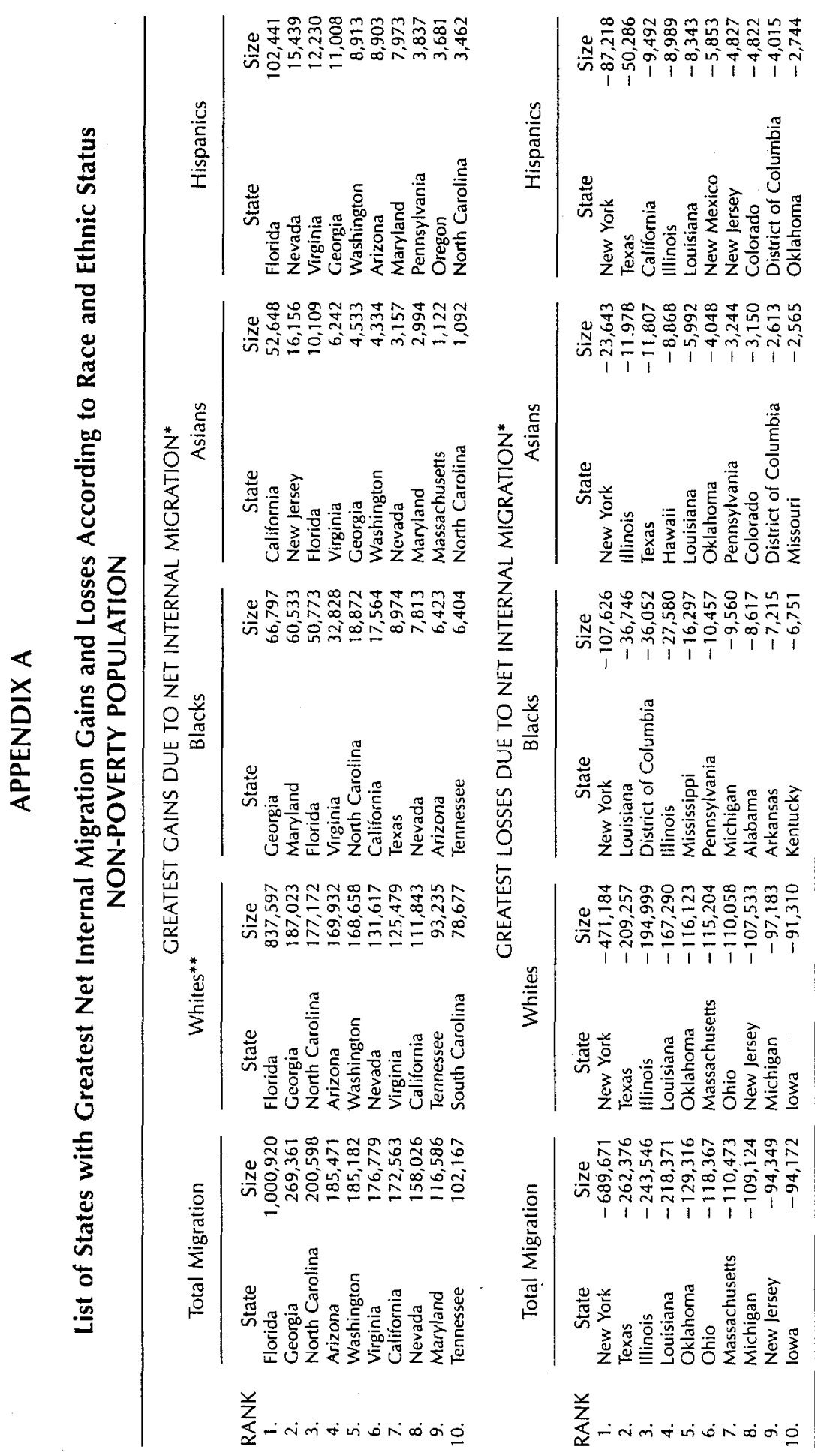

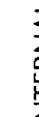

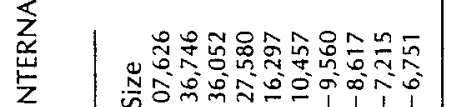

碞

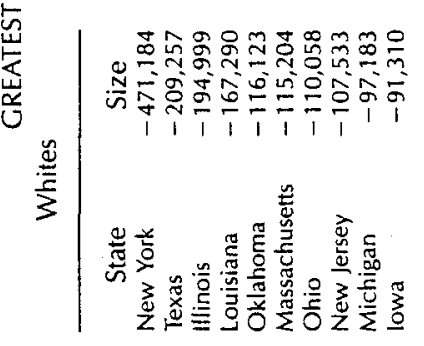

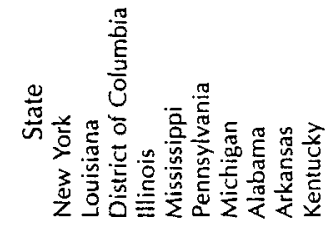

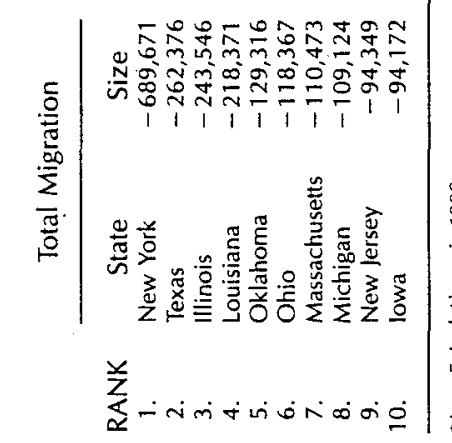


APPENDIX B

State Welfare Benefits Used in This Study*

\begin{tabular}{|c|c|}
\hline State & Annual Benefit Level \\
\hline Alabama & $\$ 5,458$ \\
\hline Arizona & $\$ 7,351$ \\
\hline Arkansas & $\$ 6,678$ \\
\hline California & $\$ 9,221$ \\
\hline Colorado & $\$ 7,623$ \\
\hline Connecticut & $\$ 8,462$ \\
\hline Delaware & $\$ 6,716$ \\
\hline District of Columbia & $\$ 6,403$ \\
\hline Florida & $\$ 7,041$ \\
\hline Georgia & $\$ 6,938$ \\
\hline Idaho & $\$ 8,010$ \\
\hline Illinois & $\$ 7,404$ \\
\hline Indiana & $\$ 7,087$ \\
\hline lowa & $\$ 8,222$ \\
\hline Kansas & $\$ 8,616$ \\
\hline Kentucky & $\$ 6,682$ \\
\hline Louisiana & $\$ 6,439$ \\
\hline Maine & $\$ 8,110$ \\
\hline Maryland & $\$ 7,497$ \\
\hline Massachusetts & $\$ 7,791$ \\
\hline Michigan & $\$ 8,389$ \\
\hline Minnesota & $\$ 9,381$ \\
\hline Mississippi & $\$ 5,390$ \\
\hline Missouri & $\$ 7,024$ \\
\hline Montana & $\$ 8,457$ \\
\hline Nebraska & $\$ 8,043$ \\
\hline Nevada & $\$ 7,503$ \\
\hline New Hampshire & $\$ 8,292$ \\
\hline New Jersey & $\$ 7,184$ \\
\hline New Mexico & $\$ 7,361$ \\
\hline New York & $\$ 8,694$ \\
\hline North Carolina & $\$ 6,860$ \\
\hline North Dakota & $\$ 8,478$ \\
\hline Ohio & $\$ 7,281$ \\
\hline Oklahoma & $\$ 7,591$ \\
\hline Oregon & $\$ 9,051$ \\
\hline Pennsylvania & $\$ 7,916$ \\
\hline Rhode Island & $\$ 8,508$ \\
\hline South Carolina & $\$ 6,635$ \\
\hline South Dakota & $\$ 8,347$ \\
\hline Tennessee & $\$ 6,029$ \\
\hline Texas & $\$ 6,179$ \\
\hline Utah & $\$ 8,884$ \\
\hline
\end{tabular}


APPENDIX B Continued

State Annual Benefit Level

Vermont

Virginia

Washington

$\$ 9,384$

West Virginia

Wisconsin

$\$ 9,628$

Wyoming

$\$ 8,244$

* Benefits represent the average of combined AFDC and Food Stamp Levels (assuming maximum AFDC for State) for years 1985 and 1988, adjusted by the CPI to 1992 Dollar values. Values were further adjusted for State variations in Cost of Living from 1985 and 1989 estimates by MCMahon and Chang (1991)

Source for Combined AFDC/Food Stamp Benefit Levels: Overview of Entitlement Programs: 1993 Green Book, US House of Representatives, Committee on Ways and Means, Washington, DC: US Government Printing Office, 1993. 